\title{
An Archaeological Assessment of the Drainage Improvement Area on the Northeast Side of Alamo Hall, and Home of Former Mayor Wilhelm Thielepape (41BX507), San Antonio, Texas
}

David L. Nickels

Follow this and additional works at: https://scholarworks.sfasu.edu/ita

Part of the American Material Culture Commons, Archaeological Anthropology Commons, Environmental Studies Commons, Other American Studies Commons, Other Arts and Humanities Commons, Other History of Art, Architecture, and Archaeology Commons, and the United States History Commons

Tell us how this article helped you.

This Article is brought to you for free and open access by the Center for Regional Heritage Research at SFA ScholarWorks. It has been accepted for inclusion in Index of Texas Archaeology: Open Access Gray Literature from the Lone Star State by an authorized editor of SFA ScholarWorks. For more information, please contact cdsscholarworks@sfasu.edu. 
An Archaeological Assessment of the Drainage Improvement Area on the Northeast Side of Alamo Hall, and Home of Former Mayor Wilhelm Thielepape (41BX507), San Antonio, Texas

Creative Commons License

(c) (1) \& 8

This work is licensed under a Creative Commons Attribution-NonCommercial 4.0 International License 
An Archaeological Assessment of the Drainage Improvement Area on the Northeast Side of Alamo Hall, and Home of Former Mayor Wilhelm Thielepape (41BX507), San Antonio, Texas

\section{David L. Nickels}

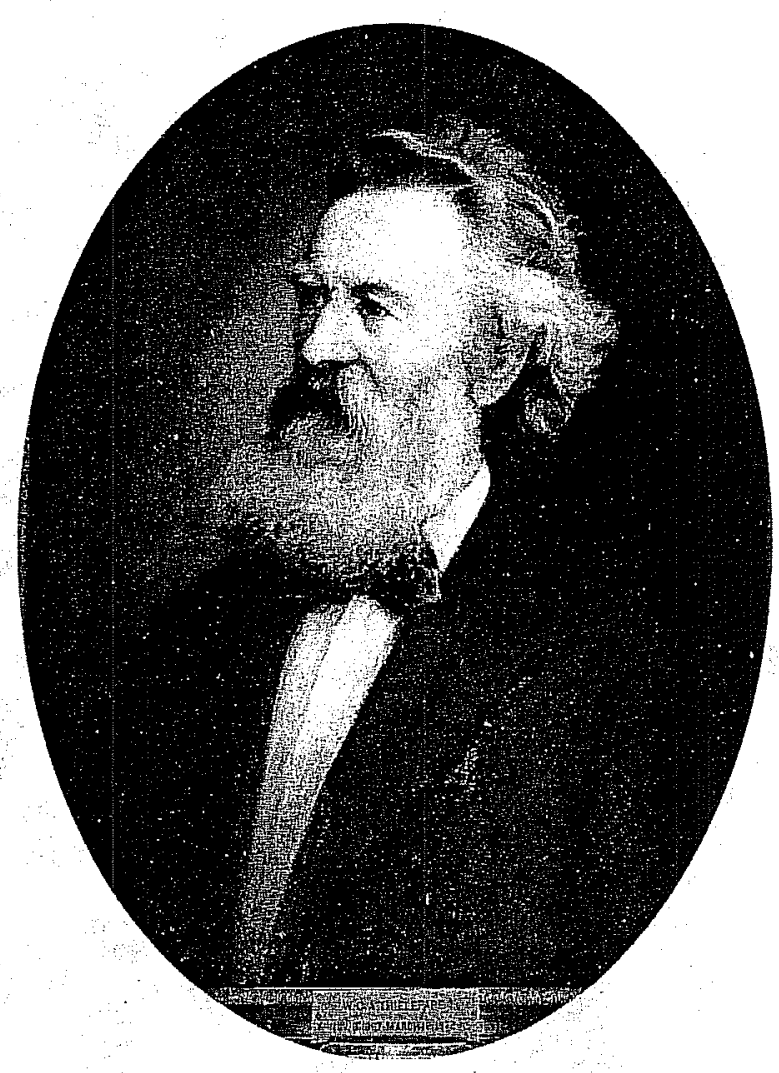

Center for Archaeological Research The University of Texas at San Antonio Archaeological Survey Report, No. 244 1999 



\section{An Archaeological Assessment of the Drainage Improvement Area on the Northeast Side of Alamo Hall, and Home of Former Mayor Wilhelm Thielepape (41BX507), San Antonio, Texas}

\section{David L. Nickels}

Robert J. Hard, Jack D. Eaton, and Thomas R. Hester Principal Investigators

Texas Antiquities Permit No. 219 
The following information is provided in accordance with the General Rules of Practice and Procedure, Chapter 41.11 (Investigation Reports), Texas Antiquities Committee:

1. Type of investigation: Testing

2. Project name: Alamo Hall Drainage Project

3. County: Bexar County

4. Principal investigators: Robert J. Hard, Jack D. Eaton, and Thomas R. Hester

5. Name and location of sponsoring agency: The Daughters of the Republic of Texas, The Alamo, San Antonio, Texas

6. Texas Antiquities Permit No.: 219

7. Published by the Center for Archaeological Research, The University of Texas at San Antonio, Texas 78249-0658, 1999

A list of publications offered by the Center for Archaeological Research is available. Call (210) 458-4378; write to the Center for Archaeological Research, The University of Texas at San Antonio, 6900 N. Loop 1604 W., San Antonio, Texas 78249-0658; e-mail to car@lonestar.utsa.edu; or visit CAR's Web site at http://www.csbs.utsa.edu/org/car/index.htm. 


\section{Abstract}

In December 1979, before installing a drainage system on the southwest corner of the grounds of the Alamo behind Alamo Hall, the Daughters of the Republic of Texas contracted with the Center for Archaeological Research to conduct investigations to determine the possibility of significant subsurface cultural material being impacted by the proposed construction. Four hand-excavated units revealed the walls of an adobe structure believed to be the home of former mayor Wilhelm Carl August Thielepape. Structural remains of a detached kitchen structure were also discovered. Archival research indicates the house was built by 1854 and demolished ca.1936. 


\section{Contents}

Abstract. .....................................

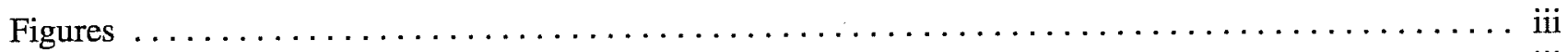

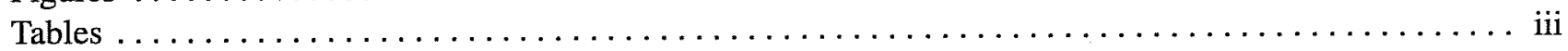

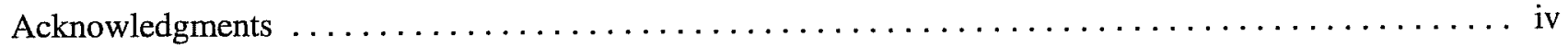

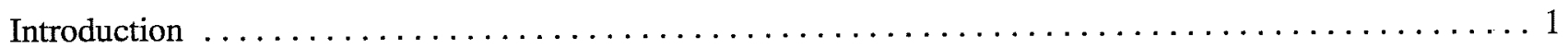

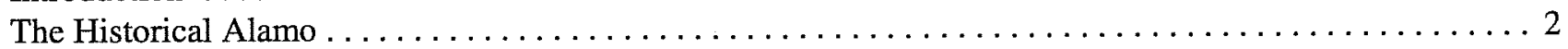

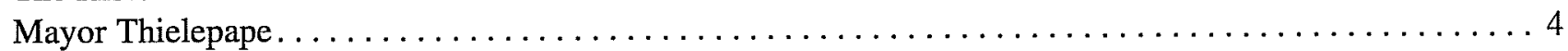

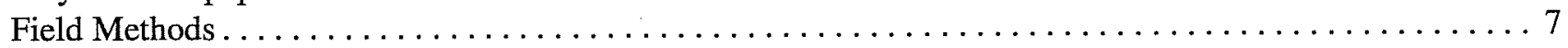

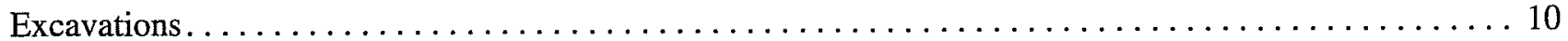

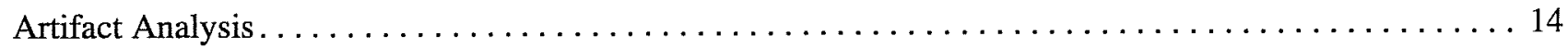

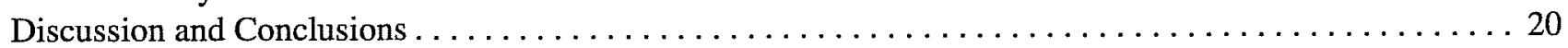

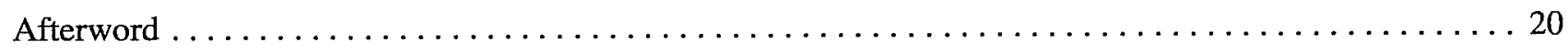

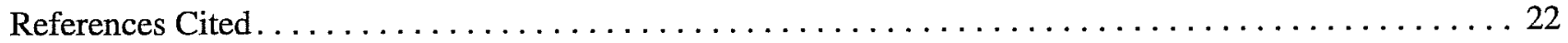




\section{Figures}

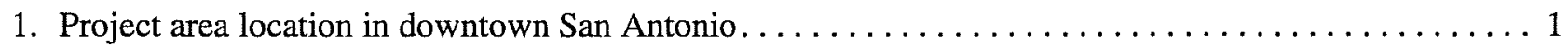

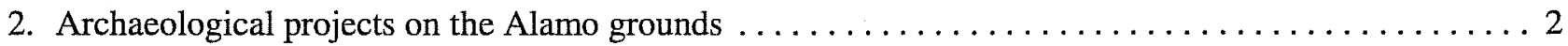

3. Herman Lungkwitz's 1854 drawing of Alamo Plaza $\ldots \ldots \ldots \ldots \ldots \ldots \ldots \ldots \ldots \ldots \ldots \ldots \ldots \ldots$

4. Sanborn Insurance map ca.1930 showing the Thielepape house and detached kitchen . . . . . . . 8

5. Excavation units exposing Thielepape house and kitchen structures $\ldots \ldots \ldots \ldots \ldots \ldots \ldots \ldots \ldots$

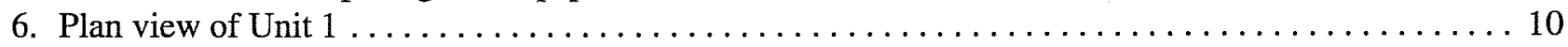

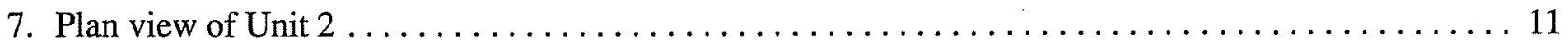

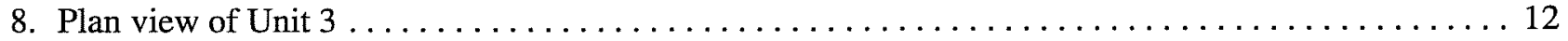

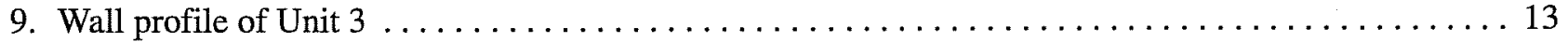

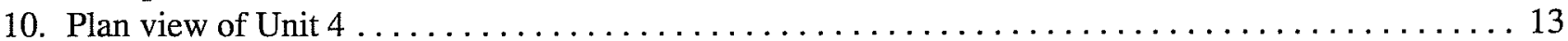

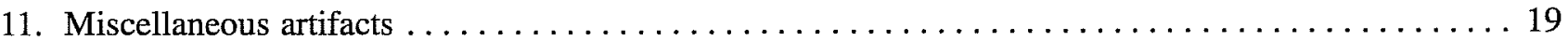

\section{Tables}

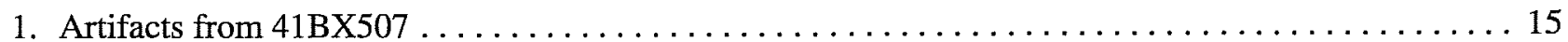

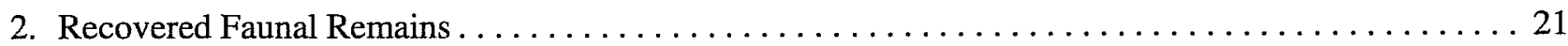




\section{Acknowledgments}

The author wishes to extend a sincere thank you to the Daughters of the Republic of Texas for their help throughout this project. Anne Fox located the field notes and other data that comprise the basis of this report, identified the ceramic artifact types, and willingly shared her expertise throughout. Johanna Hunziker identified the faunal remains. The field workers who ably excavated this historically significant structure were CAR crew chief James Ivey, crew members Waynne Cox, Lois Flynn and Roberta McGregor, and volunteer Cecil Peel. Roger Wayne Johnson's draft manuscript on Mayor Thielepape was a helpful beginning. A special thanks to Bruce Moses and Fernando Londoño for their superb illustrations of selected artifacts, and to Anne Fox, Waynne Cox and James (Jake) Ivey for their critical review and comments on this publication. As always, Marcie Renner's assistance with editing has been invaluable. Thomas R. Hester and Jack D. Eaton are acknowledged for their participation in the field phase of the project. Thanks also go to Robert J. Hard, CAR director, for seeing this project through to its completion. 


\section{Introduction}

Mission San Antonio de Valero or the "Alamo," as the mission is more commonly known, is located in the heart of modernday San Antonio, Texas (Figure 1). Located on the southeast corner of the Alamo grounds is the current library/administration building known as Alamo Hall, which is operated by the Daughters of the Republic of Texas (Figure 2).

In September 1979, drainage problems around Alamo Hall necessitated disturbing the substratum for installation of an underground drainage system. The Center for Archaeological Research (CAR) was contacted by Mrs. Virginia Nicholas, then chair of the Alamo Committee, Daughters of the Republic of Texas (DRT), to investigate the possibility of significant cultural subsurface deposits within the proposed work area. Environmental and engineering consultants R. W. Opitz \& Associates provided a site plan detailing the scope of work. The plan included installation of underground drainage inlets and tubing along the north and east sides of Alamo Hall, and the regrading of the ground surface in that area.

Archival research by CAR staff revealed that the subsurface remains of at least one historic structure were located within the proposed work area. This house, belonging to former Mayor Wilhelm Thielepape, occupied the area between Alamo Hall and Bonham Street. Herman Lungkwitz's 1854 drawing of Alamo Plaza shows the house at the junction of Crockett and Bonham streets (Figure 3). The drawing shows that the house was located on the north side of the street, in the area where regrading and a future patio addition to Alamo Hall were planned. Further investigation indicated that little soil disturbance had occurred here in the past, so it was likely the foundations would be found in relatively undisturbed condition.

CAR proposed to conduct selective and limited excavations in the planned drainage improvement area, concentrating most of the effort in the footprint of the 1850 s-period structure. The purpose was to examine the depth of modern land fill and to note the location, condition, and depth of any significant cultural remains. This information was needed to determine if the current plans for drainage control in the study zone would disturb any important historical remains; and if so, to provide recommendations to avoid and protect, or if necessary, mitigate those remains.

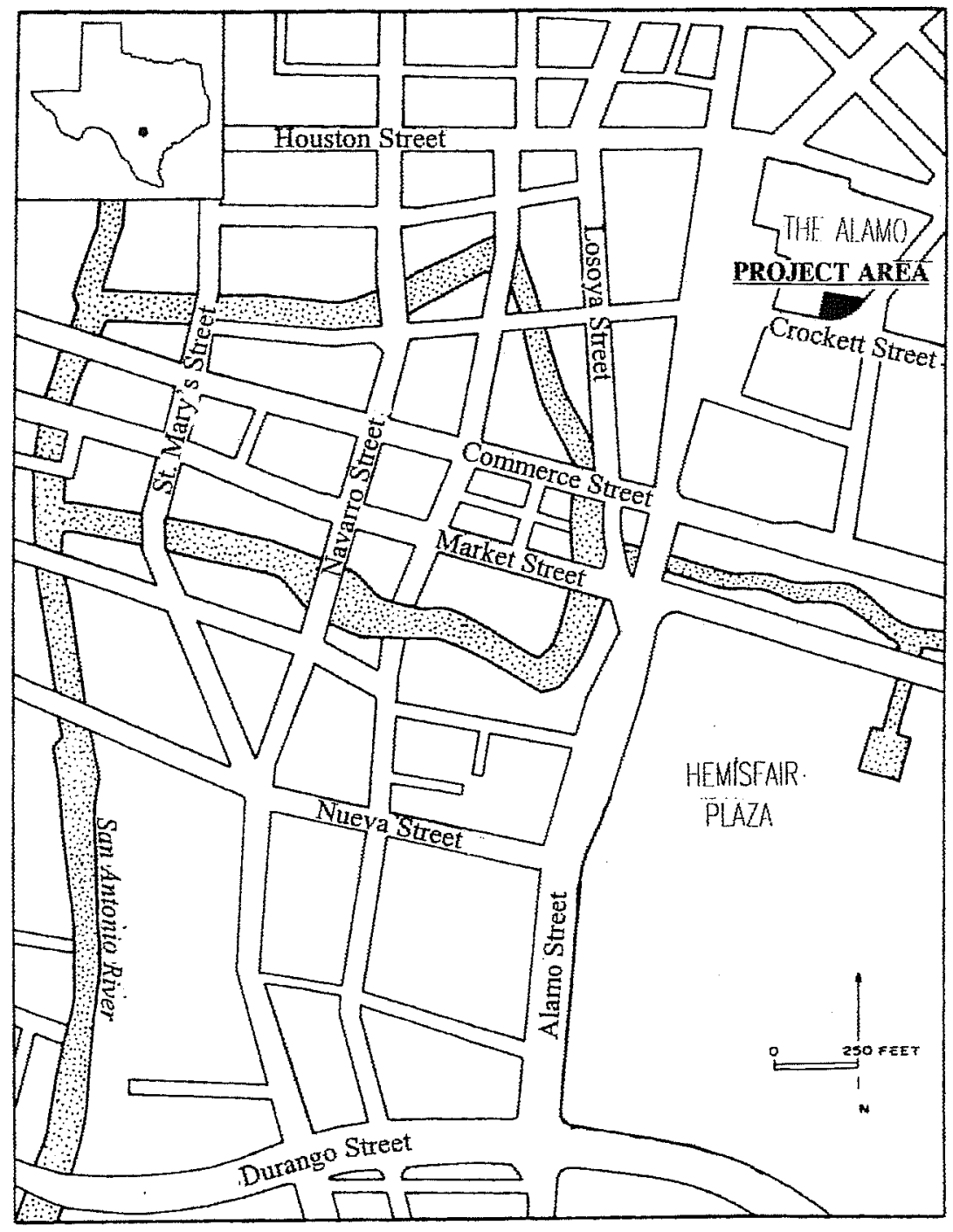

Figure 1. Project area location in downtown San Antonio. 


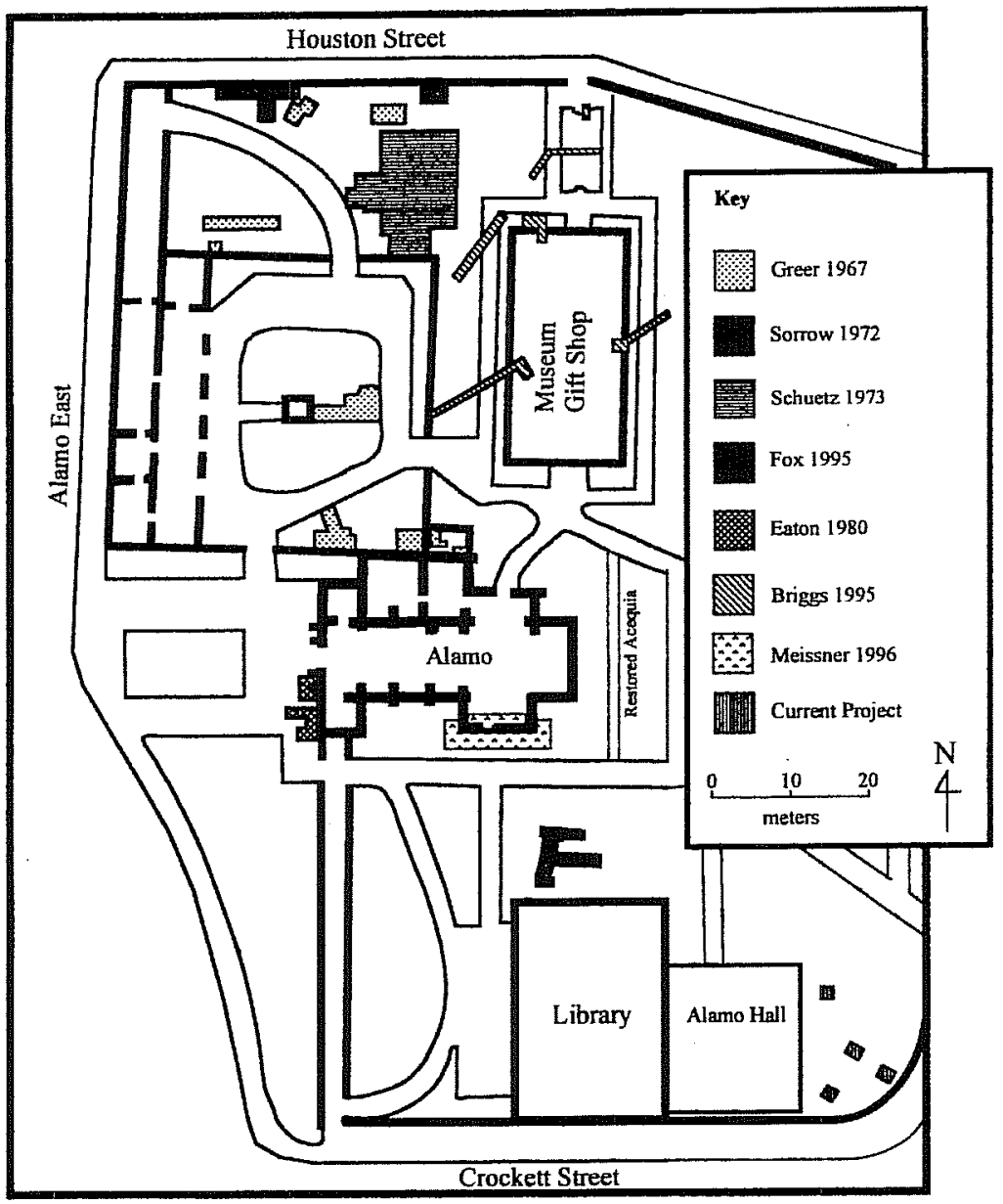

Figure 2. Archaeological projects on the Alamo grounds.
In December 1979, CAR was contracted by the DRT to proceed with the proposed excavation. The field work was accomplished in January 1980 by four CAR staff archaeologists and one experienced volunteer.

\section{The Historical Alamo}

On April 25, 1718, Father Olivares and Governor Don Martín de Alarcón arrived in the San Antonio River valley with seven families intending to settle in this as-yetuntamed land. Shortly thereafter, Father Olivares founded Mission San Antonio de Valero near San Pedro Springs. On May 5, 1718, Governor Alarcón established the Villa de Béjar in the same area (Hoffman 1967 [1935]:49). A jacal structure was placed at the temporary mission site, and an area suitable for irrigation ditches and a dam was delineated just below Olmos Springs (Hoffman 1967[1935]:317-318) in what is now Brackenridge Park.

For reasons that are not clear, in 1719 the mission was moved to the east bank of the

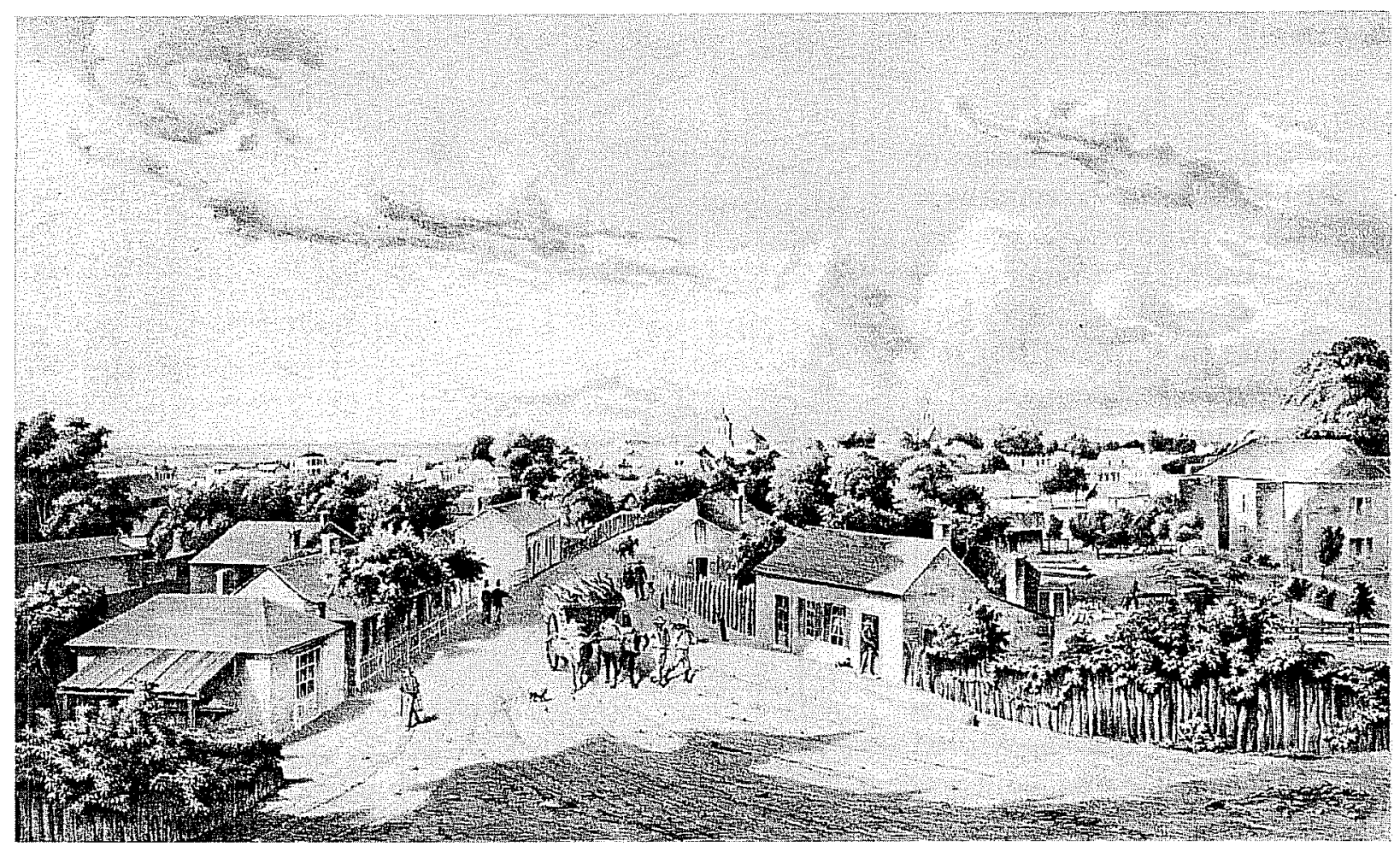

Figure 3. Herman Lungkwitz's 1854 drawing of Alamo Plaza. Copy in the Daughters of the Republic Library. 
river (Habig 1968:41), near today's Commerce Street bridge. Once again a jacal structure was constructed, but it was apparently destroyed by a hurricane in 1724 (Fox et al. 1976:2-4 [citing Barker 1929:36-38]). The mission was moved for the third time (de Paredes 1727:35-38) to today's Alamo grounds. Once again, a jacal structure served as a temporary church while the convento rooms, a granary, and an acequia system were being constructed (de Paredes 1727:35-38). A stone church with a flat roof served as an interim house of worship beginning in 1730 . Construction of a permanent stone church began in 1744 (Fox et al. 1976:2-4 [citing Barker 1929:36-38]). Unfortunately, the foundation was not adequate for the structure, and the first stone church fell sometime between 1758 and 1762 (Chabot 1937:45; De Zavala 1917:18; Fehrenbach 1978:33). Adjoining the church were rows of Indian quarters, a friary, a granary, a craft gallery, and mission offices (Cox et al. 1994:2). A sacristy, solidly constructed of stone and mortar with an arched roof, was built. It served as the church until 1793 when the mission lands were secularized and divided by order of a royal decree from Spain (Cox et al. 1994:4; James Ivey personal communication 1996).

In 1810 , fearing encroachment of the French from the Louisiana Territory, Spain dispatched a detachment of troops-the Compañía Volante de San Carlos de San José y Santiago de Parras del Álamo-to reinforce a smaller number of soldiers stationed at the Presidio de Bexár. The troops occupied the mission buildings and immediate grounds until civil unrest in Mexico south of the Rio Grande forced their departure. The Catholic church retained control of the church and convento, allowing local converts use of the buildings (Cox et al. 1994:4-5).

After Mexico's revolution from Spain, Mexican soldiers occupied the Alamo in 1823. They were quartered in the convento structures (Fox 1992:4), and the lands and buildings north and west of the church and convento were sold to private citizens (Ivey 1978:9). The southwest portion of the Alamo grounds had been previously awarded to the mission's carpenter during secularization proceedings.

Texans assumed command of the Alamo which, had been heavily fortified by General Martín Perfecto de Cós, Santa Anna's brother-in-law, and valiantly defended the Alamo during the Texas Revolution of 1836. Although the defenders of the Alamo were soundly defeated and killed by Mexican General Santa Anna's soldiers, their efforts have been immortalized through the years. Santa Anna's subsequent defeat and surrender at San Jacinto led to the establishment of the Republic of Texas (Hogan 1975).

During the Texas Republic period (1836-1845), the Alamo church and convento fell into ruins. In 1849 the United States Army began repairs. Alamo Plaza quickly developed as a center of commerce centered around the army's use of the church and convento for storing westward-bound supplies, as well as for stables, storehouses, workshops, and offices (W. G. Freeman's “Report of Quartermaster Depot at the Alamo, Office of the Quartermaster General, San Antonio." National Archives, Washington, D.C., File Box No. 1). On the western side of the plaza, the remnants of the compound walls were used to support jacal and thatched-roof hovels (Cox et al. 1994:14).

In the $1850 \mathrm{~s}$, the area south and east of the church was platted into town lots, and Crockett, Travis, and Bonham streets were named (Bexar County Deed Records [BCDR], Volumes A2:159, H1:109). On the southeast corner of the plaza, the Menger Hotel opened in 1859 (San Antonio Daily Herald, 2 February 1859). With the outbreak of the Civil War, Confederate soldiers occupied the Alamo church and convento. During that same period the second floor and roof of the church had to be repaired after they were damaged by fire (Fox et al. 1976:21).

The city purchased the area immediately to the south of the chapel in 1871, and reserved it as open space adjoining Alamo Plaza and the Plaza de Valero (BCDR, W1:237). Alamo Plaza continued to develop as a market center through the 1870 s and 1880 s (Fox et al. 1976:22). The city post office was relocated to southeast Alamo Plaza in 1877 (Gallegly 1970:28). Urban development struck Alamo Plaza with diligence during the last two decades of the nineteenth century: streets were widened to $60 \mathrm{ft}$, sidewalks were installed, and stone structures replaced those of wood and adobe (Cox 1994:22).

Despite developers' dreams of tearing down the Alamo church and convento, the structures were preserved. Clara Driscoll purchased the convento structure and land in 1904; the state of Texas assumed the property in 1905 and appointed the Daughters of the Republic of Texas as legal guardians. The church itself had been 
purchased previously by the state of Texas. Through the efforts of concerned citizens and city and state governments, the Alamo grounds have been left relatively unscathed and now provide a wealth of archaeological data.

\section{Mayor Thielepape}

Wilhelm Carl August Thielepape was born in Wabern, Kurhessen, Germany on July 10, 1814. His father, Werner Philipp Thielepape, was of Finnish and Swedish descent and worked as a government official; his mother, Elisabeth Thomson, was of English descent. Wilhelm was the fourth of seven children (Albrecht 1976:1). Unfortunately very little is known about his childhood and early adult years. He graduated from the Gymnasium in Kassel, and although this is not confirmed, he probably followed his three older brothers through either the University of Gottingen or the University of Bonn. By 1840 he was practicing engineering and architecture in Berlin and Bielefeld. His talent in music is documented in 27 surviving songs and duets, one of which was Lieder, written for his future wife, Mathilde Gossing. He and Mathilde married in March 1841 (Albrecht 1976:2).

Political forces in Germany during the 1830 s and 1840 s created serious dishevel, pitting liberal modernization of the social systems against conservative elements wishing to retain individual values and independence. With the political climate changing toward liberalism, many Germans chose to emigrate to other countries. Wilhelm's brother George Justus was one of those conservatives who chose to come to Texas. George Justus Thielepape followed Prince Solms to Texas and settled in New Braunfels in 1844 (Albrecht 1976:2; Weinert 1965:4). Whether George encouraged Wilhelm to emigrate or Wilhelm was anxious to follow is not clear. Either way, Wilhelm booked passage aboard the Franziska, departing on October 28, 1845, and landed in Galveston on January 11, 1846. After evaluating the pros and cons of permanently relocating himself and his family to Texas, he returned to Germany later that same year. In 1850 , his brother George also returned to Germany, but only long enough to marry and to encourage Wilhelm to resettle permanently in Texas. Both families settled in the German colonization's society in Indianola, on Matagorda Bay. Wilhelm resided with his wife and two daughters in a cabin which he built (Albrecht 1976:2-3).

Wilhelm first came to San Antonio in 1852 looking for work. Finding the prospects of a growing city encouraging, he returned to Indianola for a few years before returning to San Antonio in the spring of 1854 . This time he brought along his wife, two daughters, and two new sons (Albrecht 1976:4). Wilhelm's niece recalled that her uncle's family moved into a small adobe home on Nacogdoches Street (Weinert 1965:35), now known as East Crockett Street. Wilhelm was undoubtedly delighted with the prospects of not only work, but also the German social life in San Antonio. As for work, he advertised his skills as an architect, engineer, and surveyor in the San Antonio Zeitung; as for his social interests, he immediately joined the Mannergesang-Verein as a first tenor, and soon was named as co-coordinator for the choral group (Albrecht 1976:4).

Soon after leading his group in the Second Sangerfest in New Braunfels in 1854, he attended the state political assembly. At the assembly the German element of attendees pushed through resolutions advocating that the state support the following:

1) Popular election of the president, U.S. senators and judges, as well as postal, tax and administrative officers;

2) The Monroe Doctrine;

3) Scaled income and inheritance taxes; and

4) State's rights on the slavery issue, declaring "slavery is an evil, the removal of which is absolutely necessary according to the principles of democracy. Since slavery concerns only the states, we demand that the federal government refrain from all interference in pertaining to slavery. However, if a state determines the removal of this evil, it may call on the federal government for aid in the execution of its decision (Albrecht 1976:4-6)."

The latter point infuriated the Anglo-American slave owners of Texas; so much so that all German conservatives and their societies were branded as suspicious (Albrecht 1976:4-6). It even split the German community from within, to the extent that the 
Mannergesang-Verein stopped meeting due to lack of attendance (Albrecht 1976:6-7). Such ingratiation followed Wilhelm into and throughout his terms as mayor of San Antonio.

As evidence of his versatility as a gifted and talented individual, Wilhelm advertised in the Zeitung in 1855 that he was available to give drawing lessons to those interested in his services. The same year, he went into the lithographic business with Adolf Douai, editor of the Zeitung. Wilhelm used his talents to carve a caricature of the German opposition, the "KnowNothings," an anti-foreign political organization. The caricature and a view of Main Plaza were used as logos on the Zeitung. Wilhelm did practically all the work overhauling old presses and keeping the newspaper going, so Douai generously gave title and all profits from the paper to him. Still available for survey work, he managed to travel 80 miles west and survey the townsite of Uvalde for landowner Reading W. Black (Albrecht 1976:8-9).

By 1856 the German community made up one-third of San Antonio's population (McGuire 1983:20). Accordingly, German social life in the city was very prominent. A common bond formed by Thielepape and 19 other members of the German community resulted in the founding of the Casino Club, of which Thielepape would later serve as president. Prominent members of the club included painter and artist T. C. Hummel; legislator and future judge Jacob Waelder; and founder of the German-English School, Gustav Thiesen. This literary and theatrical social club first met in T. C. Hummel's home, then on the second floor of the Hummel Building on Commerce Street (Chabot 1937:384), before moving to the end of what was Casino Street, near the present-day Hertzburg Circus Museum (Everett 1975:114,125).

In the fall of 1856, Thielepape and noted nineteenth century Texas landscape artist Hermann Lungkwitz were employed painting backdrops and sets for a play cast by the Casino Club. Wilhelm's friendship with Lungkwitz was endearing and long lasting. Lungkwitz took the opportunity to recognize his close friend by including him in an 1852 sketch, standing in the doorway of his adobe home on the corner of Crockett and Nacogdoches streets (McGuire 1983:18, 126). The sketch was used for a painting of the same in 1853 (McGuire 1983:18,132) (Figure 2).

Wilhelm Thielepape also became an accomplished photographer. He teamed up with Lungkwitz and professional photographer William DeRyee in presenting their "Mammoth Agioscope," a kaleidoscope of portraits that appeared to fade in and out through the use of reflection from two lanterns. The portraits and photography were undertaken in DeRyee's studio on Commerce Street. The show became so popular that the three took it on the road as far away as Indiana and Missouri (McGuire 1983:20-21).

In 1857 Thielepape designed a new Casino Hall, which was built in 1858 by the same man who built the Menger Hotel in 1859, Johann Hermann Kampmann. Apparently not one to remain idle, Wilhelm also worked as a bookkeeper for several local merchants. By April 1858, he and other members of the Casino Club organized a German-English School in San Antonio. He helped plan the first building and sat on the school board of trustees. He organized a benefit concert for the school on January 29, 1859, which netted proceeds of $\$ 121.95$ (Albrecht 1976:10).

Commissioned to design a new Comal County courthouse, he moved with his family to New Braunfels in the fall of 1859 . While there he also designed and built Dr. Theodore Koester's home. His work there completed, he moved back to San Antonio in either June or July 1861 (Albrecht 1976:1-11).

The Civil War years were rough on the conservative German immigrants who had so voiced their proUnion stance in past assemblies. It is unclear as to the exact whereabouts of Wilhelm during those years. Although his family remained in San Antonio, Thielepape may have withdrawn to either Eagle Pass or into Mexico with the help of friends Samuel Maverick, Dr. Ferdinand Herff, and Reading Black (Albrecht 1976:11-14).

The exact time of Thielepape's return to San Antonio is also unclear, but he was definitely back by July 1865 . When federal troops had not arrived to take control of San Antonio by July 21, 1865 , the pro-union German community decided that the city needed a symbol of 
peace and unity. Wilhelm and his 12-year-old son Eduard, helped raise a Union Stars and Stripes on top of the Alamo. In a show of new unity, 25 men were assigned to guard the flag.

Following the war, Wilhelm continued to encourage and support the arts and social life of San Antonio. He founded the Beethoven Gesangverein soon after the war ended and performed several concerts through 1867 , including two more for the German-English School.

Texas came under military control by United States congressional enactment of the First Reconstruction Act of 1867. The Reconstruction Act divided the southern states into five military districts. Each of the five districts was placed under military control, with the objective being to remove former Confederate leaders and initiate suffrage for freed blacks. Although the initial command of Texas was given to General Philip Sheridan, General J. J. Reynolds had assumed the command by September 1867 (Connor 1971:217218). By authority of General Reynolds, Wilhelm Thielepape was appointed mayor of San Antonio, and served from November 8, 1867 to March 28, 1870. By Governor E. J. Davis' authority under the Enabling Act, Wilhelm was appointed to serve from March 28, 1870, to March 12, 1872 (Corner 1890:67). The Enabling Act was the fourth of five acts passed by the Twelfth Texas Legislature in 1870 and 1871. The acts, described by Texas Democrats as the "Obnoxious Acts," were designed to reform Texas government during Reconstruction (Connor 1971:218-223). The local San Antonio Herald newspaper as well as Secessionist sympathizers scorned both Thielepape and his appointment under Federalist rule (Albrecht 1976:16). Such was the tumultuous political climate that challenged Mayor Wilhelm Thielepape.

Mayor Thielepape's efforts in improving San Antonio were commendable. Under his administration, the city built needed bridges across the San Antonio River, allowing for unprecedented expansion of the city to the east of the river, and laid the first macadam street in the city. The army was enticed to move its headquarters from San Antonio to New Braunfels because of the latter's bid to bring the railroad through its city instead of San Antonio. The railroad was an essential supply and transportation lifeline for the army in the late-nineteenth century and Mayor Thielepape recognized the significance of rail transportation for the future development of San Antonio. He lead negotiations with the army and the railroad investors to bring the rail through San Antonio. His efforts account for the army's continued presence in latetwentieth-century San Antonio (Albrecht 1976:16).

Throughout his tenure as mayor, Wilhelm Thielepape retained his love for fine music. He continued presenting concerts for charity and art, while maintaining a political influence in the same. As an outgrowth of the Casino Club, Wilhelm organized the Beethoven Gesangverein Singing Club and held rehearsals at his house "behind the Alamo on Crockett Street" once a week. Wine and other refreshments were served at a cost of $\$ .25$ per club member. The singing club's first concert was on October 14, 1865, at the German-English School (McGuire 1983:30).

One of Thielepape's most earnest desires as mayor was to secure the source of the San Antonio River as city property. After much negotiation, he announced in 1872 that the area generally known today as Brackenridge Park could be purchased by the city for the then-meager sum of $\$ 50,000$. Charges of political insider dealings became rampant. Despite the opposition, the deal was almost consummated when Mayor Thielepape and his staff were abruptly removed from office (San Antonio Express [SAE], 22 March 1872). An opposing group of Anglo-Americans, whose anger had been simmering for years, was delighted. No doubt their influence had much to do with the mayor's departure from office. By and large, the citizens of San Antonio were the real losers; in the 1890 s, the city ended up purchasing the approximate same lands for several million dollars (Albrecht 1976:18-19).

On August 17, 1872, the San Antonio Weekly Herald [SAWH] boasted of a "Valuable Residence at Auction." The valuable residence, to be auctioned by Frost \& Bros, was that of Mayor Thielepape. The ad read,

On Tuesday, Aug. 27th, 1872, We will sell at Auction the Residence now occupied by $\mathrm{Mr}$. W.C.A. Thielepape, on Nacogdoches street, near the house of Mr. H. Grenet. The house contains four rooms and a hall, with a good, substantial 
kitchen adjoining; a well of good water, and elegant shade trees. The lot is large, centrally situated, with an extensive front on Nacogdoches [now East Crockett] street. Till day of sale offers for said place will be entertained. If not sold previously, it will then be sold, absolutely without any reserve or qualification. The owner will be present to execute good and sufficient title to the property [SAWH, 17 August 1872].

Following his removal from office, Thielepape continued to host Sangerfests and city concerts, started a junior chorus, and taught piano lessons. He remained active among the German-Americans, singing and giving speeches to such groups as the West Texas Turn Verein (Turner District), a group dedicated to gymnastics, health, and spiritual well being (Everett 1975:49). He advertised himself as available for work as an architect and engineer (SAE, 31 March and 4 April 1874), and served as president of the San Antonio Meat \& Packing Company until it sold at trust in 1874 (SAE, 22 March 1874).

By 1873, Thielepape's son Eduard had finished school and moved to Chicago. After reading accounts of the tremendous rebuilding to be done there after the Chicago fire, Wilhelm was convinced that he should be a part of that effort. After turning over directorship of the Beethoven, he checked his family into the Menger Hotel the evening of April 15, 1874, before departing for Chicago (SAE, 16 April, 1874). No evidence is available that indicate he ever returned to Texas.

While in Chicago, Thielepape maintained his appreciation for social life and fine music, serving as an agent of the Deutsche Gesellschaft (German Association). During this time he worked as an architect, a bridge engineer, and a bookkeeper. He even designed and installed automatic street car stop indicators on Chicago's trolleys. Sadly, his wife Mathilde passed away in 1894. Even after retiring, he remained active in the German singing societies, composing his last Lied in 1899, at the age of 85 (Albrecht 1976:20-21).

In 1900 Thielepape returned to Berlin and then to Leipzig, Germany, to visit his daughter. On the return voyage he contracted a serious case of influenza. After four years of battling the disease in Chicago, Wilhelm Carl Augustus Thielepape passed away on August 7, 1904. Appropriately, his fellow singers performed at his funeral (Albrecht 1976:21-22).

In an ironic twist, some 53 years after he left office, someone else was mistakenly identified as Mayor Thielepape. In 1931, the city made a concerted effort to commemorate its former mayors in paintings. The city commissioned S. Solomon of Poteet and San Antonio to paint portraits of all the past mayors. A gentlemen who Solomon initially portrayed as Mayor Thielepape was never identified, but as former mayor Sam Bell declared, "That is not Thielepape." Fortunately, Mrs. Adolph Wagner, who was a friend of the Thielepapes, produced a photograph of Wilhelm which was authenticated by former mayor C. M. Chambers and by Wilhelm's daughter, Elizabeth Thielepape. The photo was shown to Elizabeth in Chicago when she was 80 years old, and she confirmed that it was indeed her father. Artist Solomon graciously agreed that authenticity was of the utmost importance and produced another portrait for the city (SAE, 28 February 1931).

\section{Field Methods}

After reviewing a ca. 1930 Sanborn Insurance map (Figure 4) the field crew surveyed the tentative location of Mayor Thielepape's house, marked the approximate corners, and then laid out Unit 1. Four hand-excavation units (Figure 5) of various horizontal dimensions were excavated in stratigraphic levels. Stratigraphic levels were based on soil zones, and ranged from 3 to 12 inches thick. All excavation notes, and the artifacts cataloged in the laboratory refer to unit levels, not stratigraphic zones. Therefore for continuity, the term "level" is used throughout this report. Previous excavations on the Alamo grounds indicated that an average 12-14 inches of overburden had to be removed before the mid-nineteenth century surface level was uncovered (Fox 1993:14-24). The top of the foundation of the mayor's house was expected to have been at or near the same level.

Unit 1 was positioned to expose the main house fireplace, which according to an 1854 drawing (Figure 3 , would have been in the southeast corner of the 


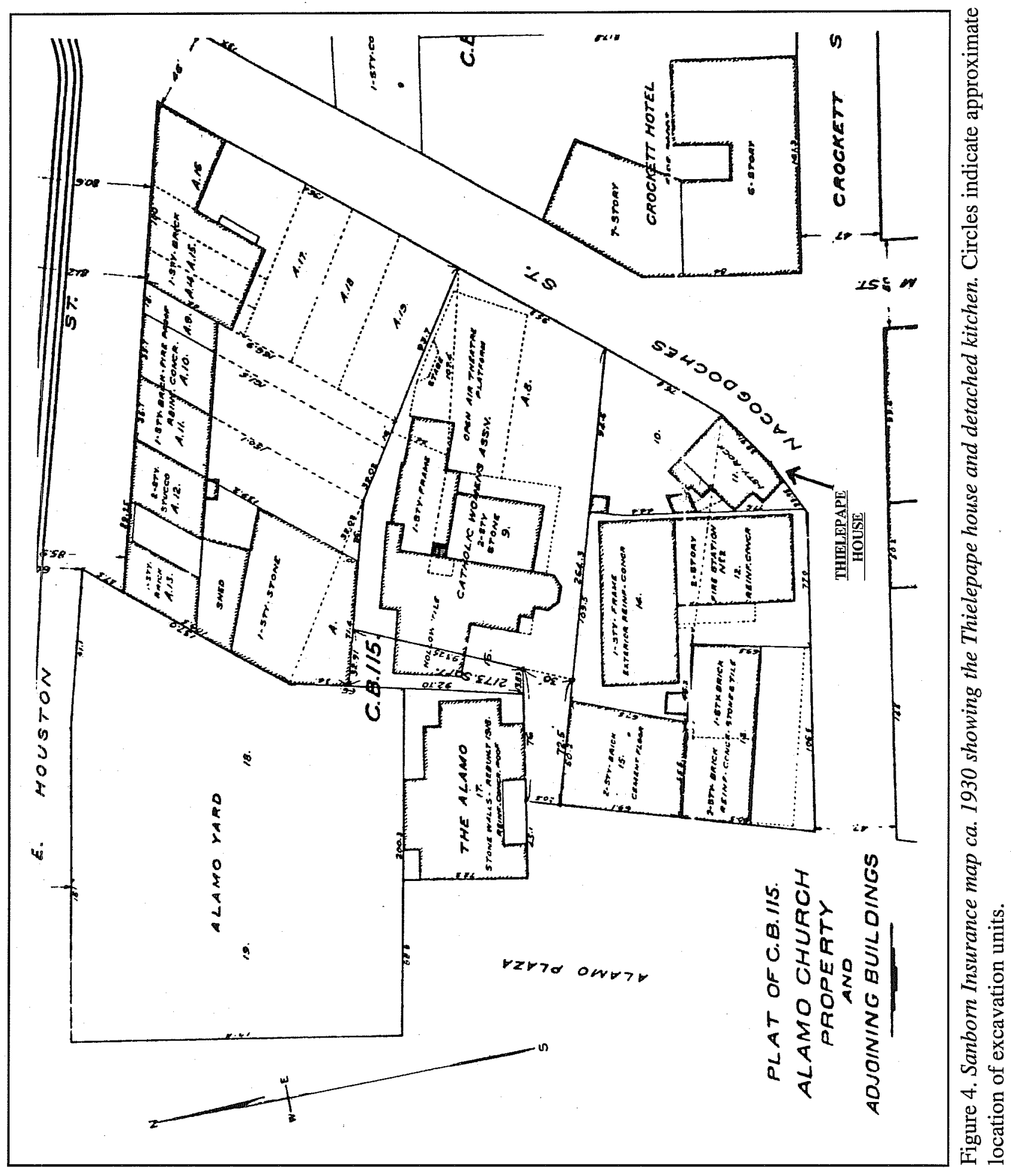




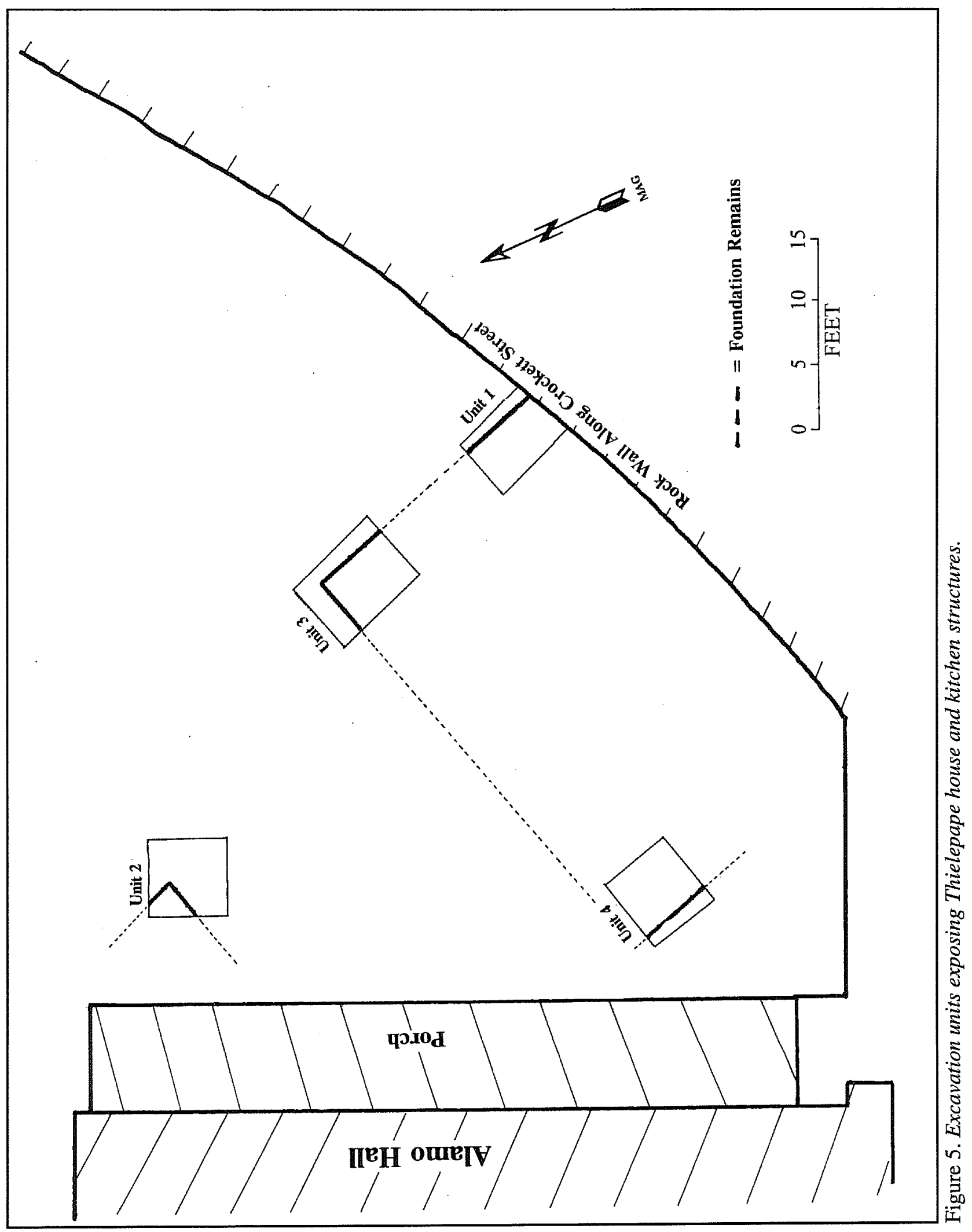


structure. A second unit, Unit 2, was laid out to uncover the northwest corner of the outbuilding. Units 3 and 4 were placed where excavators expected the north and west wall corner foundations (Figure 5).

\section{Excavations}

\section{Unit 1}

Unit 1 (Figure 6) was an irregularly shaped unit, measuring $6 \mathrm{ft} 4$ in $x 7 \mathrm{ft}$. Its shape resulted from the curvature of the stone wall along East Crockett Street (Figure 5). Approximately 6 inches of reddish brown loamy clay overburden overlay a 1-2-inch layer of black, moist clay. The clay layer changed to a grayish brown sandy loam with caliche pebble inclusions.
Interspersed within the loam were nails, pieces of broken limestone, brick fragments, a sparse number of artifacts, and caliche fill. The rubble and soils matrix was consistent throughout the unit, except in the northwest quadrant of the unit where a patch of the black clay continued downward. This soil anomaly is thought to be deposition from a planting pit. The grayish brown soils and caliche pebble matrix continued downward for another 2 inches before a 2 3-inch-thick layer of adobe was uncovered at 12 inches below the modern surface. This adobe layer sat atop a 25-inch wide cut limestone foundation along the northwest edge of the unit. At the same level, in the southwest quadrant of the unit, a layer of hard-packed adobe and rubble was encountered. This may have been a living surface, but it was not distinct. The

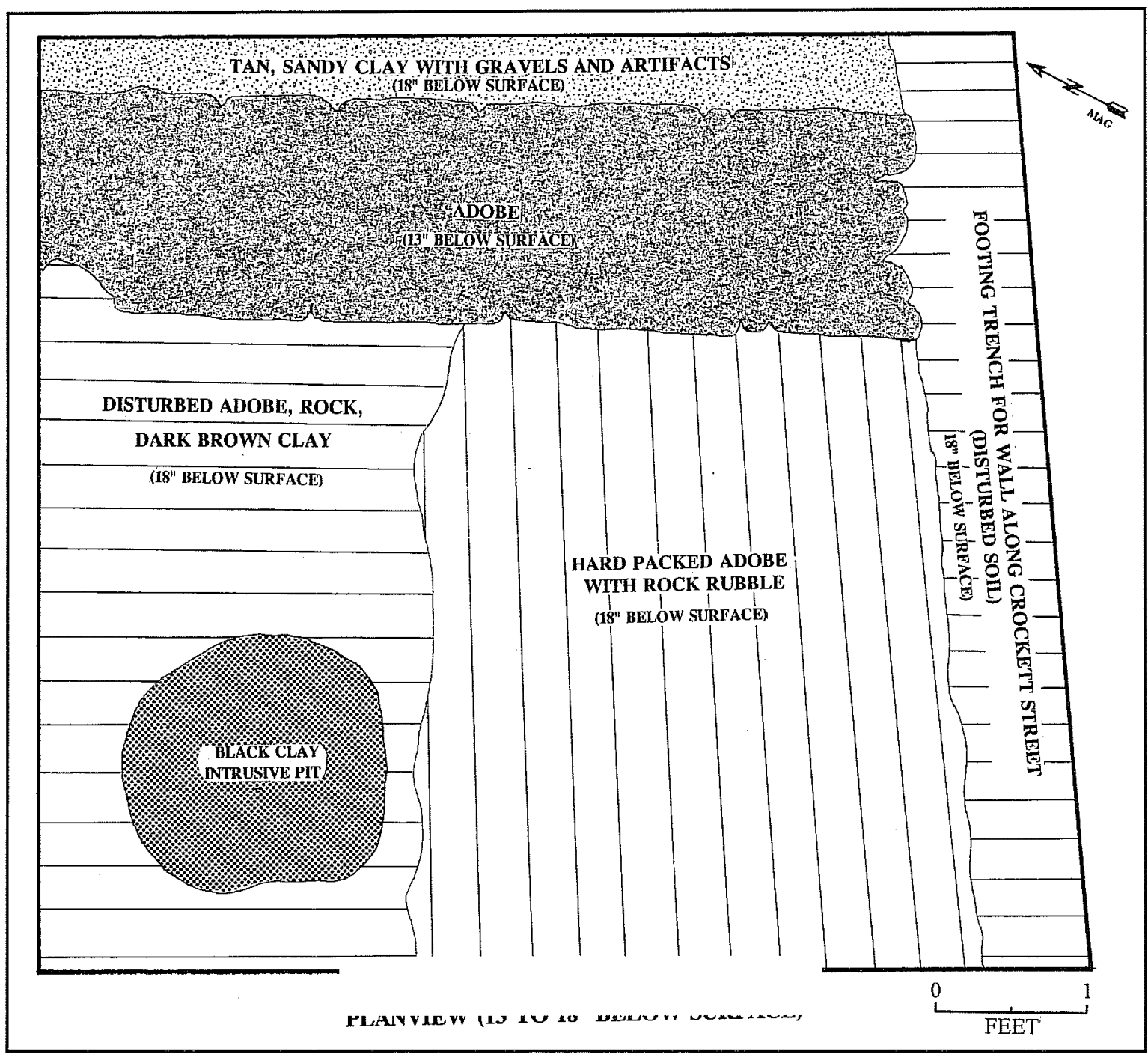

Figure 6. Plan view of Unit 1. 
northwest quadrant was badly disturbed, with the clay pit deposit surrounded by a matrix of rock, caliche, and disturbed adobe. Excavation along the west edge of the unit was interrupted by a 12-inch wide footing trench alongside the rock wall which serves as the boundary of the Alamo grounds. Excavations in Unit 1 revealed no evidence of a fireplace having existed in this area of the mayor's house.

\section{Unit 2}

Unit 2 (Figure 7) was a 6-ft-7-inch square. A nineinch overburden of reddish-brown loamy clay similar to that in Unit 1 was removed before reaching a layer of grayish-tan sandy loam with inclusions of caliche, limestone chunks, and assorted artifacts. The next distinct stratigraphic layer consisted primarily of disturbed gray clay with cobbles, grayish white building debris, and chunks of concrete. However, much of this level contained cut sandstone slabs with mortar. There was no discernable pattern to the sandstone slabs, except in the northwest corner of the unit where the mortar was still in place, and the slabs appeared to have been intentionally laid in position. The top of this slabbed surface was 13 inches below modern ground level. The fourth stratigraphic layer consisted of compacted sand and caliche, interspersed with two-inch-thick slabs of mortar. As with the sandstone slabs in the previous level, this compacted surface also appeared to have been intentionally laid. The top of this compacted floor surface ranged from 15.5-18 inches below the modern surface level. Its horizontal undulations may be attributed to natural soil expansion and shrinkage. A small surface hearth containing ash and charcoal, with a diameter of 16 in was exposed in the center of the unit. The final layer excavated contained a matrix of caliche and grayish adobe-like chunks.

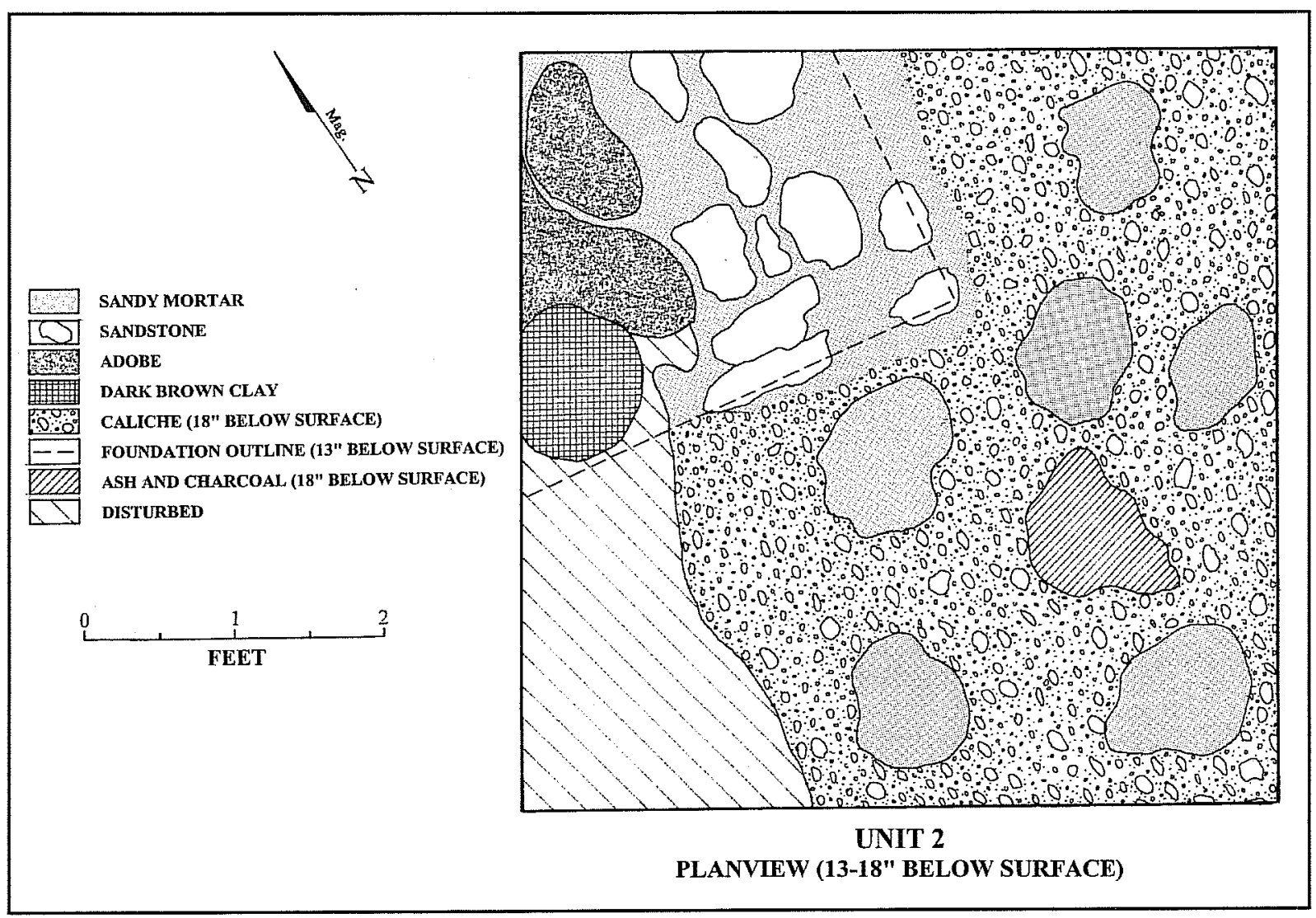

Figure 7. Plan view of Unit 2. 


\section{Unit 3}

Unit 3 (Figures 8 and 9) measured $6 \mathrm{ft} 4$ inches $x 8 \mathrm{ft}$ 4 inches, and was placed over the anticipated northeast corner of the foundation of the mayor's house. The usual overburden was removed, and as expected, the top of the cut limestone foundation was reached at 14 inches below the modern surface. The limestone blocks were laid at a $90^{\circ}$ angle, forming the northwest corner of the house foundation. At this same level, the interior of the house which had been badly disturbed, consisted of rubble, stone, and adobe. The exterior matrix, a mixture of black clay, mortar, rocks, and adobe chunks had been disturbed also. The limestone blocks were left in place and the excavation continued in the interior of the house. Between 15 17 inches below the modern surface, an undulating adobe/caliche floor, or living surface was reached. Excavation was terminated at this depth, except for a small probe along the southern edge of the unit, which revealed a black clay base layer at 25.25 inches below modern surface.

\section{Unit 4}

Unit 4 (Figure 10) was a 6-ft-8-inch square. As in Units 1 through 3 , the overburden was removed, exposing a thin layer of adobe resting on top of the cut limestone foundation. The depths of the adobe and limestone were consistent with those found in Units 2 and 3 (14 inches). The interior floor of the house had been badly disturbed, and consisted of adobe chunks, rocks and later construction rubble.

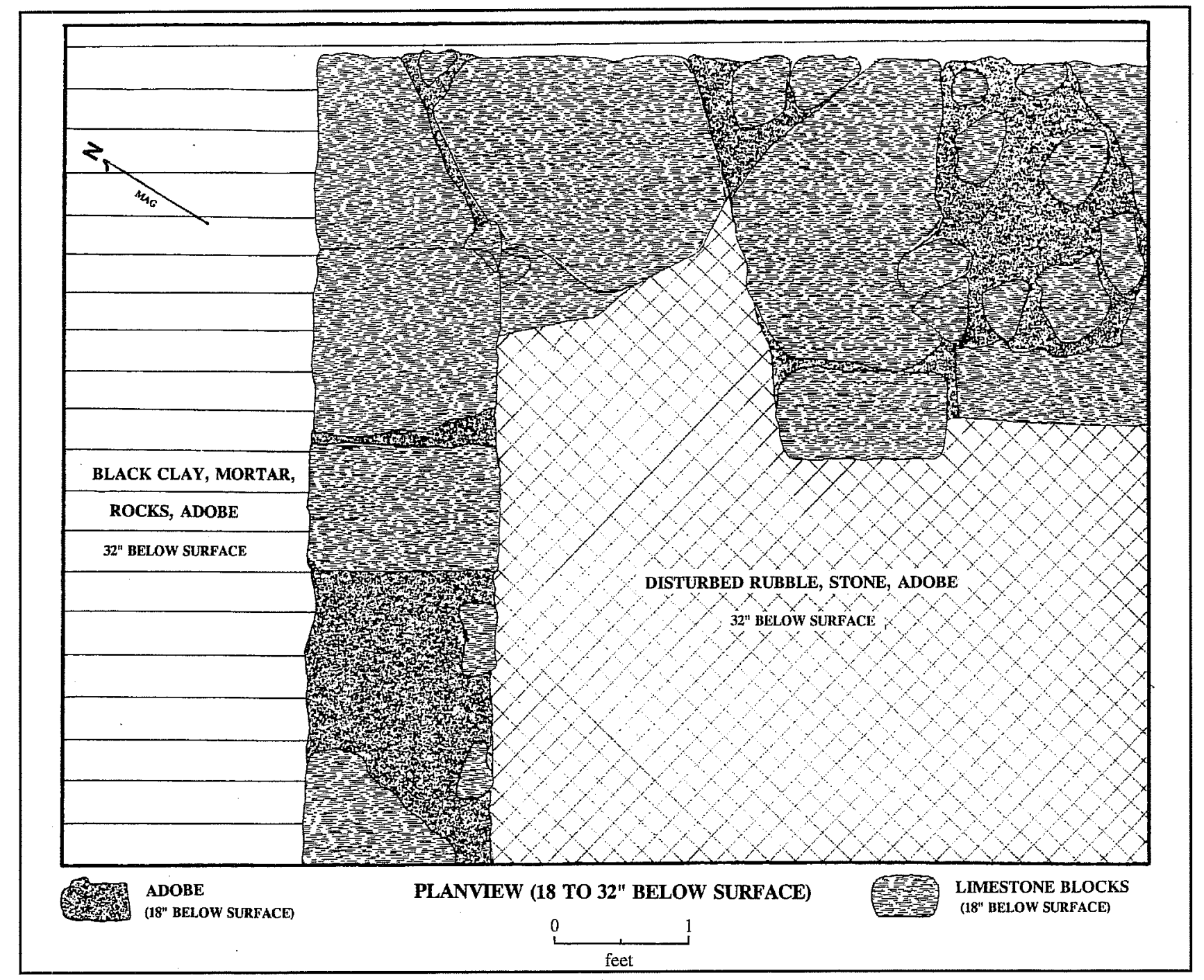

Figure 8. Plan view of Unit 3. 


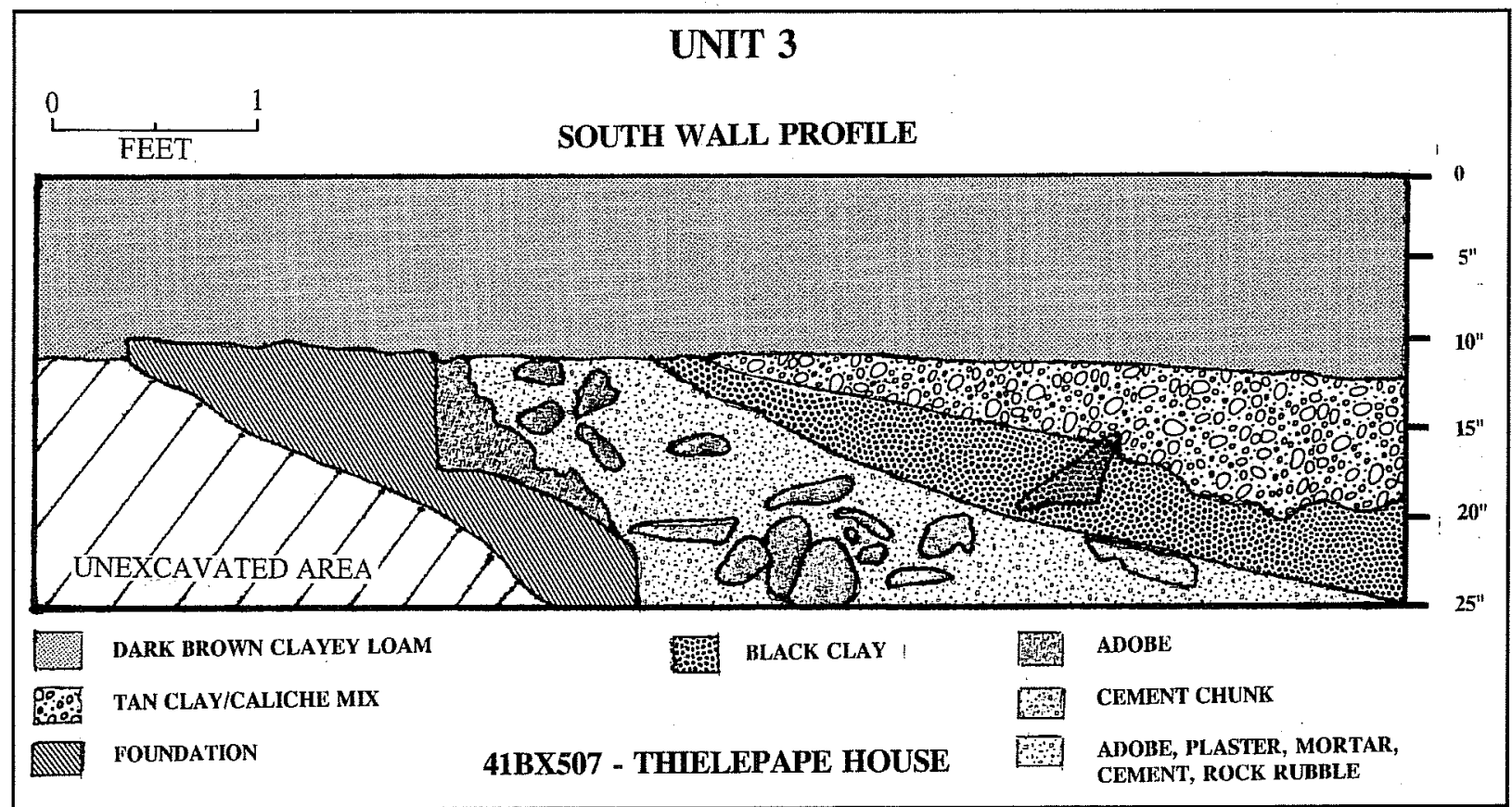

Figure 9. Wall profile of Unit 3.

Figure 10. Plan view of Unit 4.

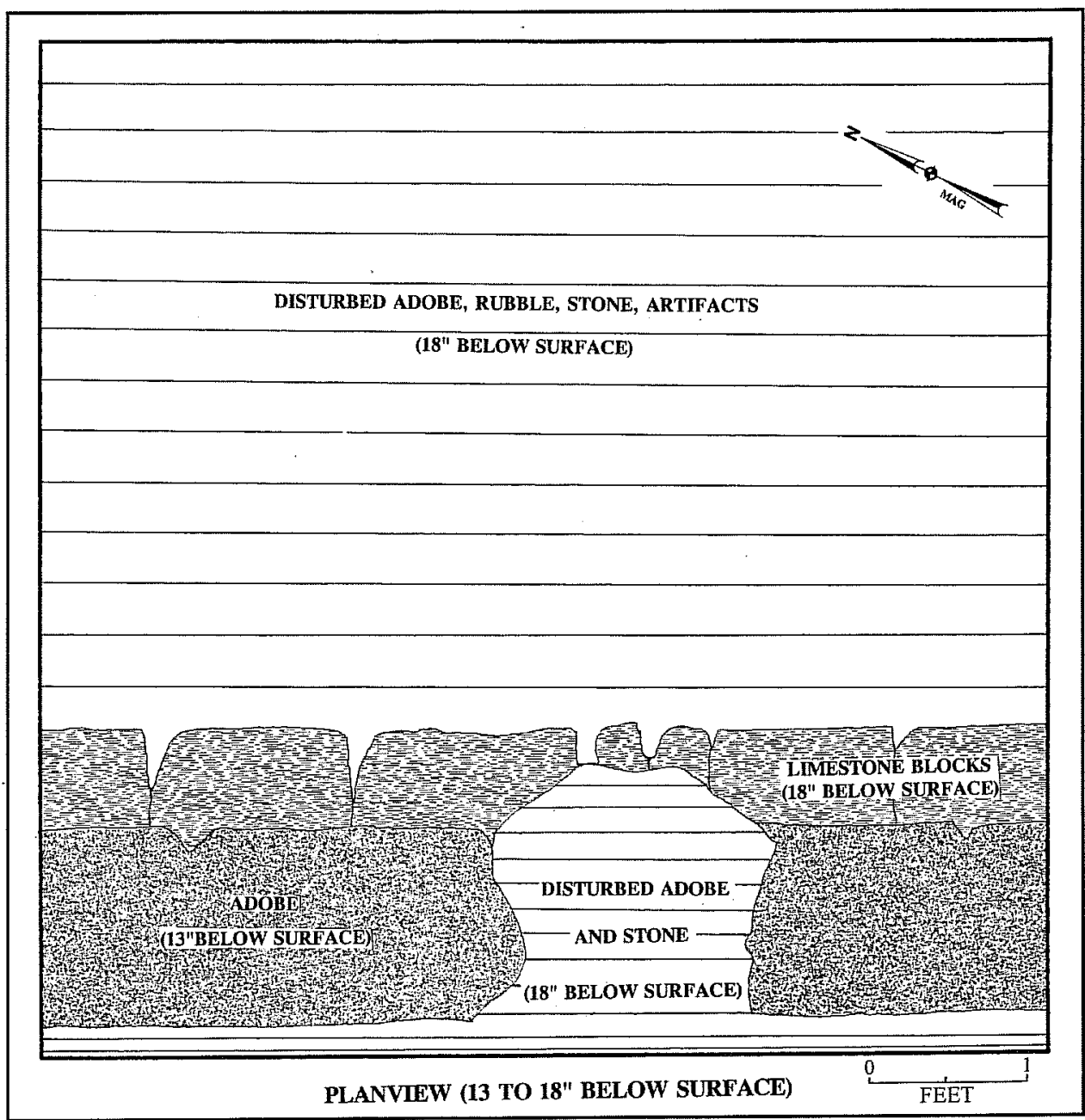




\section{Artifact Analysis}

\section{General Discussion}

Spanish occupation of sites along the San Antonio River can be generally placed within the eighteenth century (Gilmore 1974, 1975; Greer 1967; Ivey and Fox 1981; Schuetz 1969; Scurlock and Fox 1977; Tunnel 1966). After the eighteenth century, the archaeological record becomes mixed with the remains of Anglo and MexicanAmerican settlement (Ivey and Fox 1981:30-31). The artifacts that were recovered from the project provide an overall continuum of occupation from the prehistoric period into the first half of the twentieth century.

At the Thielepape house, the artifacts (Table 1) were chronologically mixed by artificial means in all units and all levels, except in Levels 4 and 5 of Unit 2 (kitchen area). During the excavation, artifact collection was left to the discretion of the excavators. The field crew in Units 3 and 4 determined that the artifacts uncovered in Level 1 were modern, and of little or no archaeological significance. Therefore, no artifacts were collected from those levels; thus their conspicuous absence from the lists in Appendixes A and $\mathrm{B}$.

Ceramics, which represent chronological, technological, and stylistic change, accounted for 7.2 percent of the artifacts (Table 1). Many types were manufactured, imported, or popularly used during specified segments in time (Fox 1986:107). Therefore, ceramic artifacts are discussed in more detail than other types of artifacts. An analysis of recovered ceramics indicates that the Spanish colonial occupation was most prevalent in Levels 4 and 5 (Table 1).

\section{Prehistoric}

An artifact believed to be brought into the project area with fill dirt was a reworked Angostura projectile point found in Unit 2, Level 2. Angostura points date to the Late Paleoindian period, ca. 6855 B.C. (Turner and Hester 1993:73-74). It had been retouched into the form of a drill. The 5-cm-long x 2-cm-wide point/drill exhibited heavy patination over its entire surface, suggesting that it had been reworked during the same period it was manufactured. Possible fluting action was evident on its proximal end. The distal end had been reworked into a drill, and had been snapped off. The Angostura/drill was believed to be intrusive to the project area because of the obvious mixed soil zones, and absence of associated prehistoric artifacts. This prehistoric tool was most probably brought to the area during landscaping activities.

\section{Spanish Colonial Period}

\section{Ceramics}

Majolica

Majolica fragments accounted for 3.6 percent ( 3 of 84) of the sherds found (Table 1). Majolica is a tinglazed ware, and can be undecorated, or have blueon-white or polychrome designs (Lister and Lister 1974:30, 1976:134-136). One piece of undecorated majolica was recovered from Unit 2, Level 1, and two blue-on-white ceramic sherds were recovered from Unit 2, Level 4. All pieces are typical of the eighteenth century (Lister and Lister 1974:30, 1976:134-136).

\section{Goliad}

Nine sherds of Goliad ware were recovered within the project area ( 9 of $84,10.7$ percent). Goliad ware is an unglazed ware and was made locally by hand. It was manufactured throughout the Spanish colonial period, and most probably adopted from the natives in the area (Ivey and Fox 1981:31-34).

\section{Sandy-Paste Lead Glaze}

Only one sherd of this type was found [(Unit 2, Level 2) ( 1 of $84,1.2$ percent)]. This type of utility ceramic was commonly used in the 1700 s, and was probably imported from Mexico (Ivey and Fox 1981:34).

\section{Plain Green Glaze}

As with the sandy-paste lead glaze, only one piece of this type was found (Unit 2, Level 4). It is also a utility ware that was imported from Mexico during the eighteenth century.

\section{Galera}

The three sherds recovered from the project area came from Unit 2, Level 4 (3 of 84, 3.6 percent). Galera 
Table 1. Artifacts from 41BX507

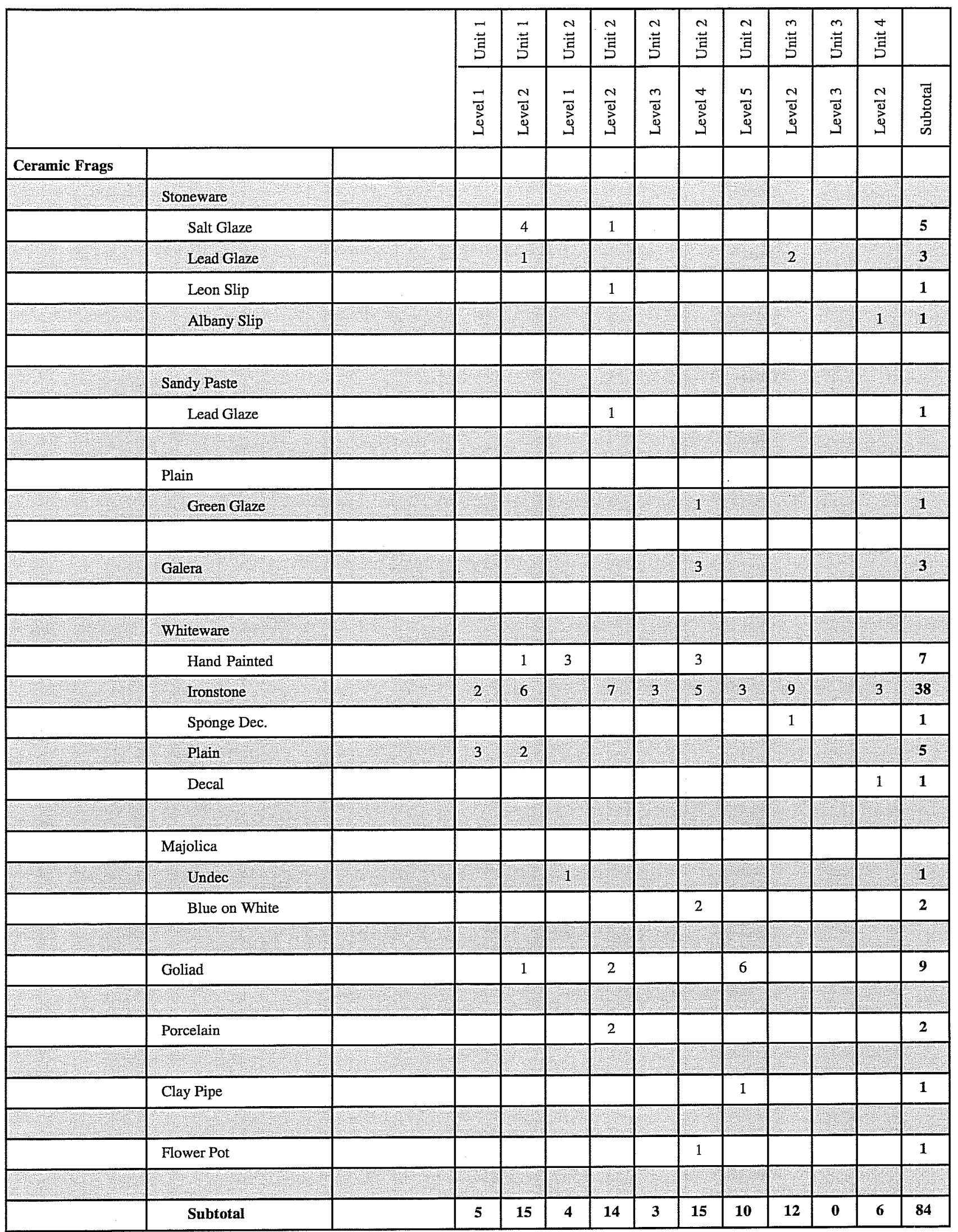


Table 1. continued

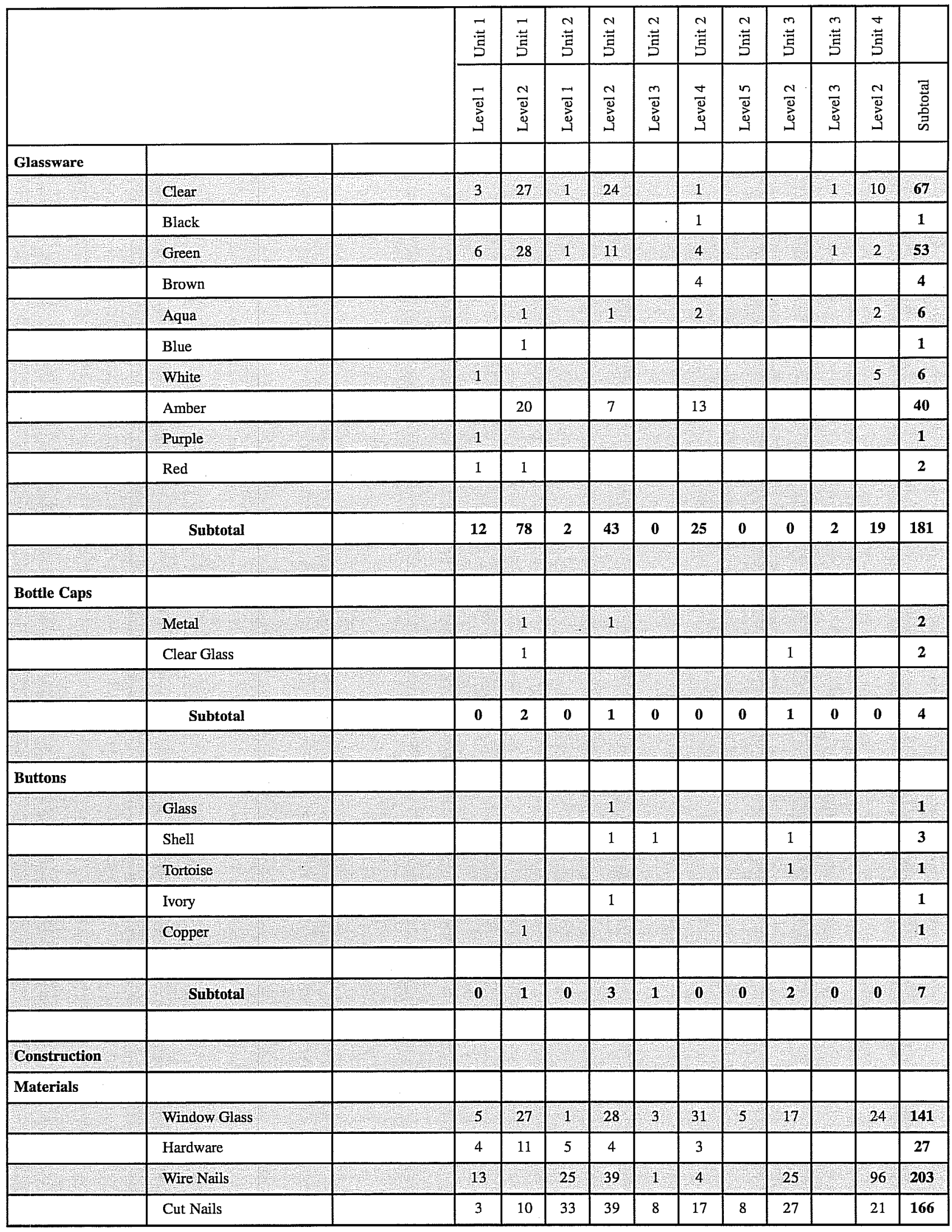


Table 1. continued

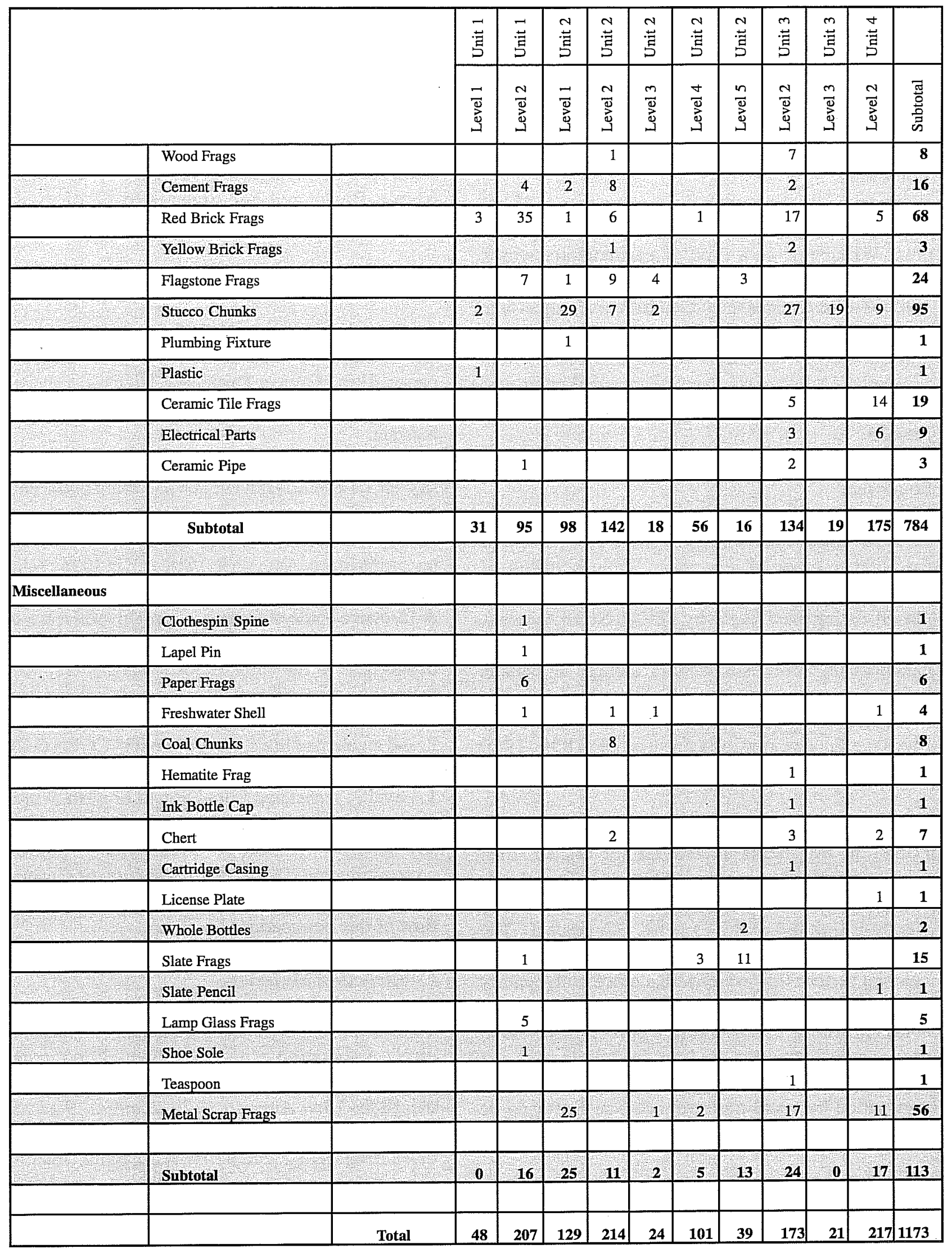


ware appears in the Texas archaeological record ca. 1750-1800 (Ivey and Fox 1981:34).

\section{Post-Spanish Colonial Period}

\section{Ceramics}

\section{Whiteware}

Whiteware was the predominant ceramic type (52 of $84,61.9$ percent) (Table 1) recovered from the project area. Whiteware is a type of earthenware which has been fired at a hotter temperature (Dial 1992:38). Whitewares recovered from the project area were of the hand-painted, ironstone, sponge-decorated, plain, and decal varieties. No complete vessels were recovered. Only one fragment bears a maker's mark; "Raddison, W.S. George, 731". It came from Unit 1, Level 2.

\section{Stoneware}

Nine fragments of stoneware were recovered during the excavation (Table 1), representing 10.7 percent of the total number of ceramics. Manufacturing of stonewares (fired to a higher temperature), either glazed, or unglazed, began by 1750 in North America. Most commonly used as utilitarian ware, they made excellent insoluble and sanitary storage containers before modern processes made them obsolete in the 1900 s. The remains of stonewares substantially increase in excavations involving 1850-1950 occupational levels (Greer 1981:13-26).

\section{Porcelain}

Porcelain fragments accounted for the smallest percentage of ceramic sherds (Table 1). Two sherds of porcelain were recovered from Unit 2, Level 2, and one from Unit 4, Level 2 ( 3 of $84,3.6$ percent). The porcelain pieces recovered were not from the Spanish colonial period; they were from a nineteenth-century children's dollhouse settings (Anne Fox, personal communication 1995). Earlier porcelain is found occasionally in mission-era sites; the fragile ware was transported on Spanish galleons to Mexico City, then transported overland northward to San Fernando de Bexar (Ivey and Fox 1981:35).
Clay pipe

The fragment recovered from Unit 2, Level 5 was brown on the convex exterior, with a lead glaze interior; however it was too small to identify with a period of manufacturing or popularity (Sudbury 1979).

\section{Flower pot}

A red ceramic sherd recovered from Unit 2, Level 4 is from a flower pot and appears to be of modern manufacturing; from ca. early 1900s through 1980.

\section{Miscellaneous}

A key with "CASINO DOOR" (Figure 11a) stamped into it was discovered in Unit 4 , Level 2, possibly a personal key of Mayor Thielepape. His close association with the Casino Club makes this possibility highly feasible.

In Unit 3, Level 2 was a Dragon soft drink bottle dating to the second quarter of the twentieth century. Rodriguez \& Son Bottling Company opened their operation in San Antonio in 1918, and in 1934 changed the name of the company to Dragon Bottling Company. A 15-ounce bottle of Dragon's Pep-Up soda water cost five cents. The Dragon Bottling Company went out of business in the early 1950s (SAE Dec 27, 1991). Interesting personal jewelry items included a handcarved shell cufflink (Figure 11b) from Unit 3, Level 2 , and a gold and black lapel pin with "CORAD COR LOQUTTUR" in raised letters (Figure 11c) from Unit 1, Level 1. Translated from Latin to English, it means "The Heart Speaks to the Heart," or "He Speaks Heart to Heart" (Clinton McKenzie, personal communication 1995). No society or organization associated with the inscription could be found at the time of this publication.

\section{Construction Materials}

Turn-of-the-century construction items were found in direct association with each other. Fragments of vitrified clay pipe, commonly used in San Antonio by the 1880s (San Antonio Daily Express, 9 October 1889), were mixed in the same level as red and yellow brick fragments, cut nails, wire nails, insulated electrical wire, and electrical outlet boxes (Unit 3, Level 2). 
Generally, nails can be used to chronologically place a structure. Cut nails were extensively used in the United States in the 1850 s through 1880 s, before being replaced by wire nails in the late 1880s (Fontana and Greenleaf 1962:44-50). The clearest delineation in the count of nail types occurred in Unit 2 (kitchen area), Levels 4 and 5 . There were 17 cut nails versus 4 wire nails in Level 4, and 8 cut nails versus 0 wire nails in Level 5 .

\section{Clothing Items}

Seven buttons were found. Five of the seven were in the kitchen area, suggesting that the area was also used for washing or sewing. Buttons are useful not only for inferring clothing styles, but also as chronological indicators. Two shell buttons were recovered from Unit 2 (Levels 2 and 3), and one from Unit 3 (Level 2). All are of the two-hole, sew-through type. Shell buttons were used as utilitarian fasteners for children's clothes, underwear, and shirts. They were made from the noniridescent freshwater shells of the type found during excavation (Table 1). Before 1900, most shell buttons were imported from Europe. By 1900, over 200 shell button factories were in operation in the United States. Popular in the United States from ca. 1890 through ca. 1910 , they were generally replaced by plastic buttons after World War I. A glass, four-hole, sew-through type button was found in Unit 2, Level 2. This type of button was popular in the United States from ca. 1840 through ca. 1910. It was also used for utilitarian wear (Crouch 1987:283, 289).

Two of the buttons were unusual. The one recovered from Unit 2, Level 2, was a hand-made, five-hole, sewthrough type made of vegetable ivory. Vegetable ivory buttons were made from tagua or coroza palm tree nuts shipped from Central and South America. After being introduced into the United States in 1859, vegetable ivory buttons reached peak popularity from ca. 1890 through ca. 1920. They were best used for utilitarian wear (Crouch 1987:287). The second unusual button was a four-hole, sew-through type made of tortoise shell. This type of shell was hand crafted during the late seventeenth and early eighteenth centuries, then experienced a revival during the last quarter of the nineteenth century (Albert and Kent 1949:65-66). Its best use would have been with costumed outerwear.
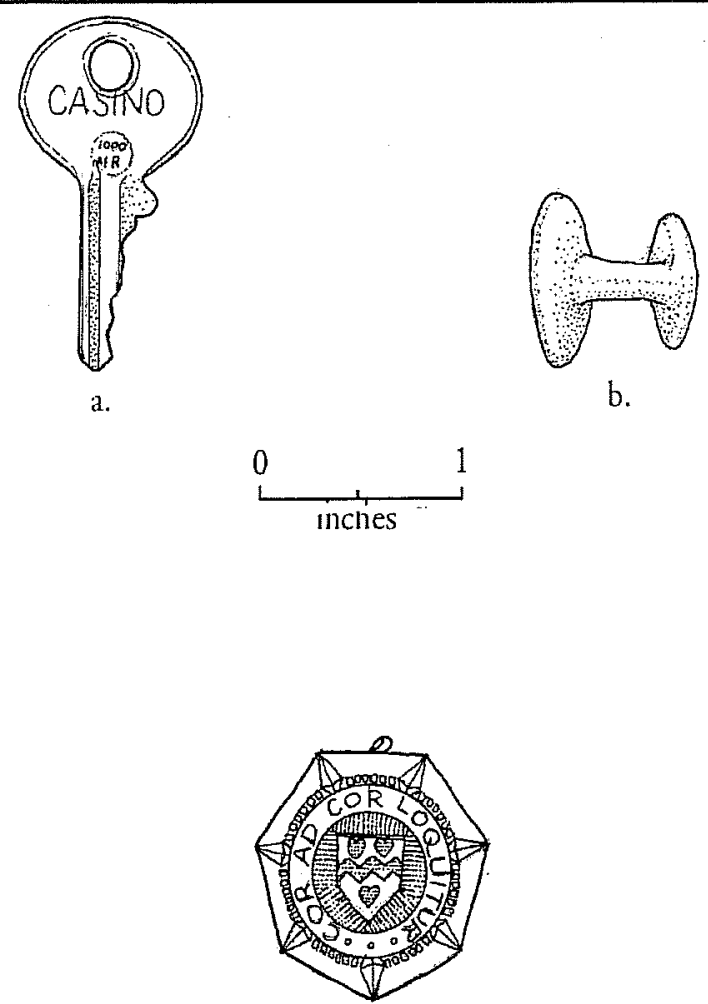

C.

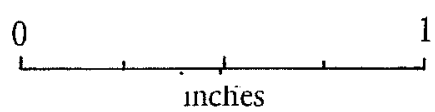

Figure 11. Miscellaneous artifacts. a- Casino Club doorkey; b- Hand-carved shell cufflink; cGold and black lapel pin.

\section{Glass}

Three whole bottles were recovered. Two olive green wine bottles were found in the kitchen area (Unit 2, Level 2). They were $11 \frac{1 / 2}{2}$ inches high, and free-blown with high basal kickups and wine-neck finishes. These bottles were in use during the mid-1800s (Switzer 1974:1-3, 29-30). The third bottle was a clear glass ink bottle (Unit 4, Level 2), not in direct association with, but possibly related to a "Watermans Ink" cap found in Unit 3, Level 2.

\section{Faunal Remains}

As with the artifacts, faunal remains were collected from all levels except Level 1 of Units 3 and 4. A 
total of 725 vertebrae bone fragments was recovered, with a total weight of $1,568 \mathrm{~g}$. Provenience information is given in Table 2. Butchering marks were evident on 111 fragments (15.3 percent), while only two showed evidence of being burned ( $<1$ percent). All remains were identified to the genus and/or species level when possible. The majority of the bone fragments $(n=646$, 89.1 percent) were so severely deteriorated that they could only be identified with either the Mammalia (mammals) or Aves (birds) taxon. The Number of Individual Specimen (NISP) remains identified was 79 (10.9 percent). These consisted primarily of cow, domestic sheep, goats, and chickens, as well as whitetailed deer and jackrabbit. Identifications were made using comparative collections at CAR, and standard textbooks (Gilbert 1990; Hillson 1986; Olsen 1964, 1968). The faunal remains recovered were consistent with the taxon types recovered in later excavations within the area of downtown San Antonio (McClure 1988; Nickels 1995).

\section{Discussion and Conclusions}

Exactly when the Thielepape house was constructed and for whom remains unknown. However, the painting by Lungkwitz (Figure 3), verifies that it was there in 1854 , and a city plat map from ca. 1930 shows both the house and the detached kitchen (Figure 5). The same map lists the house as a one-story, rock structure. Most probably the cartographers were deceived by the adobe walls which had been plastered over, giving the look of covered stone. A typical, contemporaneous example of such a structure, the Heineker house, currently stands one block east of the Thielepape remains. The Heineker house is constructed of fine-grained adobe with a soft limestone or caliche plastering to prevent the adobe blocks from eroding.

A cut-limestone foundation underneath collapsed and deteriorated, adobe walls found in Units 1,3 , and 4 confirmed that the mayor's house was in fact an adobe structure resting on a stone foundation. The north and west sides of the house were irregularly shaped (Figure 5), but the estimated size of the house was $38.5 \times 34 \mathrm{ft}$ along its south and east walls respectively. The compacted caliche floor of the house was found in Units 1 and 3.
It was common practice during the 1800 s to maintain a food preparation area separate from the living area. The detached kitchen area uncovered in Unit 2 was located approximately $15 \mathrm{ft}$ north of the house. The estimated size of the detached kitchen was 10-ft-x-9$\mathrm{ft}$ (based on Sanborn Insurance map depiction). The floor of the kitchen consisted of sandstone slabs held in place with mortar. A hearth cooking area was at the floor level and lay on compacted caliche and sand, interspersed with slabs of mortar. At least one wall of the kitchen, the west wall, appears to have been constructed of adobe, and unlike the house, had no limestone foundation.

An analysis of the artifacts recovered from each unit level provides no consistent temporal sequence (Table 1). It was apparent that considerable disturbance had caused mixing of eighteenth-, nineteenth-, and twentieth-century artifacts, most probably as a result of bulldozing. The mixing of artifacts also negated any possibility of implying functional living areas within the house.The exact date that Mayor Thielepape's house was demolished is not known. Sanborn Insurance Company maps from the early twentieth century verify its existence through 1935 . It was most probably bulldozed in 1936 , to make way for the construction of the stone wall along Crockett Street, and landscaping around Alamo Hall.

\section{Afterword}

In the years between fieldwork and publication, the drainage control project was successfully completed. Recognizing the significance of the old adobe house and so that the historic structure may not be forgotten, the Daughters of the Republic of Texas have covered the area with flagstone and marked the house corners with distinguishing bricks. 
Table 2. Recovered Faunal Remains

\begin{tabular}{|c|c|c|c|c|c|c|}
\hline Provenience & Level & Taxon & Count & Weight $(\mathrm{g})$ & Burned & Butchered \\
\hline \multirow[t]{9}{*}{ Unit 1} & 1 & UID Mammal & 5 & 9 & & \\
\hline & & Odoicoileus virginianus & 1 & 4 & & 1 \\
\hline & & Bos taurus & 1 & 1 & & \\
\hline & 2 & UID Mammal & 142 & 139 & & 10 \\
\hline & & Bos taurus & 7 & 152 & & 6 \\
\hline & & Capra hircus & 2 & 26 & & 1 \\
\hline & & Odoicoileus virginianus & 2 & 15 & & 2 \\
\hline & & UID Bird & 3 & 2 & & \\
\hline & & Total & 163 & 348 & 0 & $20(12.27 \%)$ \\
\hline \multirow[t]{15}{*}{ Unit 2} & 1 & UID Mammal & 2 & 2 & & \\
\hline & 2 & UID Mammal & 41 & 44 & & 3 \\
\hline & & Bos taurus & 2 & 45 & & 1 \\
\hline & & Odoicoileus virginianus & 2 & 5 & & \\
\hline & & Sus scrofa & 1 & 1 & & \\
\hline & 3 & Bos taurus & 4 & 43 & & 2 \\
\hline & & UID Mammal & 10 & 23 & & 3 \\
\hline & & Lepus & 1 & 1 & & \\
\hline & 4 & Bos taurus & 3 & 34 & & 2 \\
\hline & & UID Mammal & 93 & 31 & 2 & 5 \\
\hline & & Lepus & 2 & 4 & & 1 \\
\hline & 5 & UID Mammal & 26 & 33 & & 3 \\
\hline & & Bos taurus & 3 & 11 & & 2 \\
\hline & & Odoicoileus virginianus & 1 & 4 & & \\
\hline & & Total & 191 & 281 & 2 & $22(11.52 \%)$ \\
\hline \multirow[t]{7}{*}{ Unit 3} & 2 & Bos taurus & 9 & 274 & & 7 \\
\hline & & UID Mammal & 10 & 23 & & 2 \\
\hline & & Canis & 1 & 1 & & \\
\hline & & Gallus domesticus & 3 & 2 & & \\
\hline & & $U I D$ Mammal & 2 & 2 & & \\
\hline & & Ovis capra ???? & 3 & 13 & & 1 \\
\hline & & Total & 28 & 315 & 0 & $10(35.71 \%)$ \\
\hline \multirow[t]{3}{*}{ Unit 4} & 2 & Bos taurus & 31 & 328 & & 25 \\
\hline & & UID Mammal & 312 & 296 & & 34 \\
\hline & & Total & 343 & 624 & 0 & $59(17.20 \%)$ \\
\hline
\end{tabular}




\section{References Cited}

Albert, L. S., and K. Kent

1949 The Complete Button Book. John Edwards, Stratford, Connecticut.

Albrecht, T.

1976 San Antonio's Singing Mayor: Wilhelm Carl August Thielepape, 1814-1904. Manuscript on file, Daughters of the Republic of Texas Library, San Antonio.

Barker, E. C. (editor)

1929 Texas History. Southwest Press, Dallas.

Chabot, F. C.

1937 With the Makers of San Antonio. Artes Gráficas, San Antonio.

Connor, S. V.

1971 Texas: A History. AHM, Arlington Heights, Illinois.

Corner, W.

1890 San Antonio de Bexar, A Guide and History. Compiled and edited by William Corner. Bainbridge and Corner Press, San Antonio.

Cox, I. W., A. A. Fox, E. C. Newcomb, and D. Nickels

1994 A Historical Overview of Alamo Plaza and Camposanto, edited by R. J. Hard. Special Report, No. 20. Center for Archaeological Research. The University of Texas at San Antonio.

Crouch, D.

1987 In Archaeological Excavations at Fanthorp Inn State Historic Site (41GM79), Grimes County, Texas, 1982. Texas Parks and Wildlife Department. Austin.

de Paredes, M. S.

1727 Visita de las Misiones del Rio Grande del Norte por Padre Miguel Sevillano de Paredes en 15 de Octubre. Archivo General de Mexico: Historia, vol. 29. Euggene C. Barker Texas History Collection, The University of Texas at Austin.

De Zavala, A.

1917 History and Legends of the Alamo and Other Missions in and Around San Antonio. Privately published, San Antonio.

Dial, S. W.

1992 Civilian Artifacts: In Archaeological Investigations in Alamo Plaza, San Antonio, Bexar County, Texas, 1988 and 1989, edited by A. A. Fox, pp. 29-56. Archaeological Survey Report, No. 205. Center for Archaeological Research, The University of Texas at San Antonio.

Everett, D. E.

1975 San Antonio: The Flavor of Its Past. Trinity University Press, San Antonio.

Fehrenbach, T. R.

1978 The San Antonio Story. Continental Heritage, Tulsa. 
Fontana, B. L., and J. C. Greenleaf

1962 Johnny Wards's Ranch: A Study in Historic Archaeology. Kiva 28:1-2.

Fox, A. A.

1986 Ceramics. In La Villita Earthworks (41BX677): San Antonio, Texas, assembled by J. H. Labadie, pp. 107-127. Archaeological Survey Report, No. 159. Center for Archaeological Research, The University of Texas at San Antonio.

1992 Archaeological Investigations in Alamo Plaza, San Antonio, Bexar County, Texas, 1988 and 1989. Archaeological Survey Report, No. 205. Center for Archaeological Research, The University of Texas at San Antonio.

1993 Archaeological Testing and Monitoring in Connection with a Drainage Project at Mission San Juan Capistrano, San Antonio, Bexar County, Texas. Archaeological Survey Report, No. 217. Center for Archaeological Research, The University of Texas at San Antonio.

Fox, A. A., F. A. Bass, and T. R. Hester

1976 The Archaeology and History of Alamo Plaza. Archaeological Survey Report, No. 16. Center for Archaeological Research, The University of Texas at San Antonio.

Gallegly, J.

1970 From Alamo Plaza to Jack Harris's Saloon: O. Henry and the Southwest He Knew. Mouton, Paris.

Gilbert, B. M.

1990 Mammalian Osteology. Missouri Archaeological Society, Columbia, Missouri.

Gilmore, K.

1974 Mission Rosario: Archeological Investigations 1973. Archeological Report 14, Part1, Texas Parks and Wildlife Department, Historic Sites and Restoration Branch, Austin.

1975 Mission Rosario: Archeological Investigations 1974. Archeological Report 14, Part2, Texas Parks and Wildlife Department, Historic Sites and Restoration Branch, Austin.

Greer, G. H.

1981 American Stonewares. Schiffer, Exton, Pennsylvania.

Greer, J. W.

1967 A Description of the Stratigraphy, Features, and Artifacts from an Archeological Excavation at the Alamo. Report 3. State Building Commission Archeological Program. Austin.

Habig, M. A.

1968 The Alamo Chain of Missions: A History of San Antonio's Five Old Missions. Franciscan Herald, Chicago.

Hillson, S.

1986 Teeth. Cambridge University Press, Cambridge.

Hoffman, F. L. (translator)

1967[1935] Diary of the Alarcón Expedition into Texas. Quivera Society Publication, vol. 5. Reprinted. Arno, New York.

Hogan, W. R.

1975 The Texas Republic: A Social and Economic History. University of Oklahoma Press, Norman. 
Ivey, J. E.

1978 General Notes on the History of Alamo Plaza. Manuscript on file. Center for Archaeological Research, The University of Texas at San Antonio.

Ivey, J. E., and A. A. Fox

1981 Archaeological Survey and Testing at Ranchos de las Cabras, Wilson County, Texas. Archaeological Survey Report, No. 104. Center for Archaeological Research, The University of Texas at San Antonio.

Lister, F. C., and R. H. Lister

1974 Majolica in Colonial Spanish America. Historical Archaeology 8:17-52.

1976 Distribution of Mexican Majolica Along the Northern Borderlands. In Collected Papers In Honor of Marjorie Ferguson Lambert, edited by A. H. Schroeder, pp113-140. Papers of the Archaeological Society of New Mexico, Albuquerque.

McClure, W. L.

1988 The Vertebrae of Las Tiendas. Manuscript on file. Center for Archaeological Research, The University of Texas at San Antonio.

McGuire, J. P.

1983 Hermann Lungkwitz:Romantic Landscapist on the Texas Frontier. University of Texas Press, Austin.

Nickels, D. L.

1995 Excavations of the San Pedro Acequia (41BX337) on the Grounds of the San Antonio Housing Authority. Archaeological Survey Report, No. 243. Center for Archaeological Research, The University of Texas at San Antonio.

Olsen, S. J.

1964 Mammal Remains from Archaeological Sites Part I; Southeastern and Southwestern United States. Peabody Museum, Cambridge.

1968 Fish, Amphibian, and Reptile Remains from Archaeological Sites Part I: Southeastern and Southwestern United States. Peabody Museum, Cambridge.

San Antonio Daily Express [San Antonio, Texas]

18899 October

San Antonio Daily Herald [San Antonio, Texas]

18592 February

San Antonio Express (SAE) [San Antonio, Texas]

187222 March

187431 March

04 April

187422 March

187416 April

193128 February

199127 December 
San Antonio Weekly Herald

187217 August

Schuetz, M.

1969 The History and Archeology of Mission San Juan Capistrano, San Antonio, Texas (Vol. 2). Description of the Artifacts and Ethno-History of the Coahiultecan Indians. State Building Commission, Archeological Program Report 10. Austin.

Scurlock, D. and D. E. Fox

1977 An Archeological Investigation of Mission Concepci6n, San Antonio, Texas. Office of the State Archeologist, Report 28. Austin.

Sudbury, B.

1979 The Archaeology of the Clay Tobacco Pipe, edited by P. Davey. British Archaeological Reports International Series No. 60. Oxford, England.

Switzer, R. R.

1974 The Bertrand Bottles, A Study of 19th-Century Glass and Ceramic Containers. National Park Service, Washington, D.C.

Tunnell,

1966 A Description of Enameled Earthenware from an Archeological Excavation at Mission San Antonio de Valero (The Alamo). Report 2. State Building Commission Archeological Program, Austin.

Turner, S. E., and T. R. Hester

1993 A Field Guide to Stone Artifacts of Texas Indians. Gulf, Houston.

Weinert, Mrs. W.

1965 History of the George Thielepape Family. Manuscript on file. Daughters of the Republic Library, San Antonio. 
